Personality, IQ, and lifetime earnings

Gensowski, Miriam

Published in:

Labour Economics

DOI:

10.1016/j.labeco.2017.12.004

Publication date:

2018

Document version

Early version, also known as pre-print

Citation for published version (APA):

Gensowski, M. (2018). Personality, IQ, and lifetime earnings. Labour Economics, 51, 170-183.

https://doi.org/10.1016/j.labeco.2017.12.004 


\title{
Personality, IQ, and Lifetime Earnings
}

\author{
Miriam Gensowski \\ University of Copenhagen, Dep. of Economics, and CEBI, Center for Economic Behavior and Inequality, ${ }^{1}$ and IZA \\ Øster Farimagsgade 5, 1353 Copenhagen K, Denmark. Tel +45 35323036
}

\begin{abstract}
This paper estimates the effects of personality traits and IQ on lifetime earnings of the men and women of the Terman study, a high-IQ U.S. sample. Age-by-age earnings profiles allow a study of when personality traits affect earnings most, and for whom the effects are strongest. I document a concave life-cycle pattern in the payoffs to personality traits, with the largest effects between the ages of 40 and 60 . An interaction of traits with education reveals that personality matters most for highly educated men. The largest effects are found for Conscientiousness, Extraversion, and Agreeableness (negative), where Conscientiousness operates partly through education, which also has significant returns.
\end{abstract}

Keywords: personality traits, socio-emotional skills, cognitive skills, returns to education, lifetime earnings, Big Five, human capital, factor analysis

JEL: J24, I24, J16

\footnotetext{
${ }^{1}$ The activities of CEBI are financed by a grant from the Danish National Research Foundation. This paper and other versions of it have benefited immensely from discussions with numerous seminar participants. I am very grateful to everyone who provided helpful feedback, especially James J. Heckman, Steven N. Durlauf, and Gary S. Becker, Rémi Piatek, Mathilde Almlund, Katarína Borovičková, Deborah Cobb-Clark, Pia Pinger, Stefanie Schurer, Jeffrey Smith, Lucas Threinen and Philipp Eisenhauer. I am also indebted to Peter Savelyev, who generously shared his knowledge of the Terman data, and to Min Ju Lee and Molly Schnell who provided outstanding research assistance in the project's earlier stages.
} 
A growing economics literature documents effects of socio-emotional skills, often called noncognitive skills, on life outcomes ranging from wages to health - see summaries in Borghans et al. (2008) or Almlund et al. (2011). Labor market outcomes, in particular, have been shown to be influenced by skills such as self-control (Moffitt et al., 2011), Conscientiousness (Uysal and Pohlmeier, 2011; Prevoo and ter Weel, 2015), Self-esteem, or Locus of Control (Heckman et al., 2006b; Caliendo et al., 2015). This paper contributes to the body of work that studies how earnings are affected by personality traits. Personality trait measures, such as the Big Five (McCrae and John, 1992), are a popular way of proxying socio-emotional skills. This paper provides evidence on when in the life cycle personality traits are most important and for whom they have the largest effects.

The data that make this analysis possible come from the seminal Terman study (Terman, 1992). This survey was initiated in 1922 in California and followed a group of high-IQ men and women from childhood to old age. While it has been widely used for research in psychology, this paper is the first to have generated earnings profiles for ages 18 to 75 from the different waves. It combines measures on IQ and personality traits in early waves with a very long follow-up. The Terman study also contains rich background information on each participant.

The question of when personality traits matter can be addressed with the detailed age-by-age earnings measures. For most traits, the earnings effects have a hump-shaped pattern: early in these men's careers, the effects of personality traits are barely visible, but become large in their prime working years. Insofar as this life-cycle pattern is due to general mechanisms that are not specific to high-IQ individuals, these analyses could, for example, inform the forecasting of lifetime effects of skill-building interventions that target socio-emotional skills related to the personality traits observed here.

To test for heterogeneous effects of traits on earnings, I interact personality traits with education. I find statistically and economically meaningful interactions. The payoffs to two important traits, Conscientiousness and Extraversion, are more than twice as large for men with a graduate degree than for men with a bachelor's or less. Another interpretation of this interaction is that the earnings gain from higher education is larger for men who possess stronger socio-emotional skills. Most of the existing studies do not allow for a trait-education interaction, and may therefore overor under-estimate these effects of personality traits conditional on education.

With the Terman survey, the relationship between personality traits and earnings can be studied in a more detailed way than is possible elsewhere, and it fills out our understanding of the agepattern and the interaction with education. Yet the Terman sample is not representative of the general population, and was never intended to. Therefore, this study also adds to our knowledge about what determines lifetime earnings of individuals with top IQs - usually, sample sizes are too small to identify the intellectual elite. For example, it is not clear whether high-IQ children would benefit from improving socio-emotional skills. Many socio-emotional-skill building interventions are targeted at disadvantaged, and sometimes low-IQ, populations (s.a. Heckman et al., 2010, 2013; Grossman and Tierney, 1998; University of Chicago Crime Lab, 2012). This paper shows that high-IQ children also significantly benefit from positive personality traits later in life, and that they can expect positive returns to education.

The study of the high-IQ women in the Terman data is of interest as well, albeit of a rather historical nature, as they can be less easily compared to current cohorts. Only about half of the women of the Terman sample were securely attached to the labor force, and many relied on husbands as bread-winners. I therefore study women's family earnings, and demonstrate how 
women's own and husband's earnings reacted differently to women's personality traits.

Methodologically, this paper addresses a common problem to research on personality traits: whenever personality scores are used as regressors, measurement error bias is introduced because true personality is always unobserved. Instead, predicted scores of personality traits are used, and the prediction will contain some noise. An adjustment has been suggested (Bolck et al., 2004; Croon, 2002), which I develop further to apply it to a setting where the variable measured with error is interacted with an indicator for education.

\section{The Terman Survey}

The Terman survey was initiated by the prominent psychologist Lewis Terman to study the life outcomes of high IQ children. His team canvassed all schools in California, grades 1-8, in 19211922, to enrol children who scored in the top $0.5 \%$ of the IQ distribution. The sample consists of 856 boys and 672 girls, born around 1910, and who were followed until 1991, with surveys every $5-10$ years. $^{2}$ It is the longest prospective cohort study that also has data on earnings.

The Terman data have been used extensively by psychologists to study health and longevity, in relation to Conscientiousness and parental divorce or marriage. ${ }^{3}$ Only few economists have worked with the data, focusing on family outcomes (marriage, divorce, fertility - see Michael, 1976; Becker et al., 1977; Tomes, 1981), retirement behavior (Hamermesh, 1984), and health (Savelyev, 2014; Savelyev and Tan, 2015). Earnings outcomes were studied by Leibowitz (1974), but she did not exploit the longitudinal data.

Drawing on the different waves of the survey, I construct earnings histories from age 18 to 75 , as well as education and marriage profiles, for each participant. The age-by-age information stems from the feature that for many of the waves, respondents were asked about earnings in each of the 4 previous years separately. Earnings are imputed through linear interpolation for years without information. The earnings measures for all estimations are annual earnings after tuition in 2010 U.S. Dollars (CPI adjusted), truncated at the 97 th percentile, before tax. ${ }^{4}$ For inactive workers, as well as for the deceased, earnings are zero. For female participants, the Terman survey asked about their spouse's earned income. Family earnings can thus be constructed as the sum of own earnings and the husband's earnings, which are zero if the woman was not married.

The personality information in the Terman data stems from teachers and parents, who rated the participants on certain traits and behaviors in 1922, and from participants, who provided self-ratings on other items in 1940 (at around age 30). An exploratory factor analysis on all available items ${ }^{5}$ reveals a structure that is remarkably similar to traits in the well-known Big Five taxonomy: Openness to Experience, Conscientiousness, Extraversion, Agreeableness, and Neuroticism (OCEAN). Even though the Terman measures were taken about 70 years before the

\footnotetext{
${ }^{2}$ Attrition is below $10 \%$, and it is unrelated to income, education, demographic factors (Sears, 1984), or psychological measures (Friedman et al., 1993).

${ }^{3}$ Cf Friedman et al. (1993); Tucker et al. (1996); Friedman (2008); Martin et al. (2005).

${ }^{4}$ A Web Appendix to this paper, hosted at http://www.econ.ku.dk/gensowski/research/Terman/TermanApp.pdf, contains more detailed information on the data construction, estimation, and supplementary figures and tables. Section A describes the construction of the earnings profiles and tuition costs, and Section A.7 shows their distributions.

${ }^{5}$ The teacher and parent ratings are averaged within each item. In exploratory factor analysis, the researcher observes the covariance structure of the items, and determines the number of factors that capture most of the observed variation, as well as which items are associated with which factor. For the full list of items of all traits, see Section B.2 in the Web Appendix.
} 
Big Five were codified (Goldberg, 1993), the factors correspond closely to these traits, measured for example by the NEO PI-R (Martin and Friedman, 2000).

Openness to Experience, the "tendency to be open to new aesthetic, cultural, or intellectual experiences" (American Psychological Association, 2007), was measured in 1922 by ratings from teachers and parents on descriptors such as "desire to know" or "originality." Extraversion was indicated by the subject's "fondness for large groups," "leadership," and "popularity with other children," also in 1922. The remaining traits are based on self-ratings in 1940. Conscientiousness describes an individuals' persistence, order, and need for achievement. In Terman, it is measured with "How persistent are you in the accomplishment of your ends?" or "In your work do you usually drive yourself steadily?". Agreeableness describes cooperation and a preference for harmonious relationships over antagonistic behavior. An example measure is "In general, how easy are you to get on with?". Neuroticism, the opposite of emotional stability, is based on questions such as "Are you moody?". These personality traits are summarized by factor scores (Jöreskog and Sörbom, 1979; Mulaik, 2010), and predicted with the Bartlett method (Bartlett, 1937). Each item is allowed to load on exactly one factor, and this dedicated factor structure guarantees identification of possibly correlated factors. In a few cases where not all personality items are observed, they are imputed with a multiple imputation routine exploiting the covariance with the other factors.

IQ was measured at study entry in $1922 .{ }^{6}$ Scoring at 140 or higher, which corresponds to being in the top 1 of 200 children, was the criterion for being included in the study. Even though the Terman survey is selective in terms of IQ, it is not so for personality, as Martin and Friedman (2000) show. Generally, personality traits correlate only weakly with IQ (cf Dauber and Benbow, 1990). Only Openness is moderately positively correlated with IQ, at 0.2 in the Terman sample.

In this paper, earnings throughout the life cycle are associated with traits that were only assessed at a single point in time. This can be an informative exercise if these measures are good proxies for personality traits at other points in the Terman participants' lives, if they are highly correlated across time. Empirically, there is extensive evidence on such stability of traits: the rank order correlation of traits within one person over very long time spans is remarkably high (Leon et al., 1979; Costa and McCrae, 1994; Roberts and DelVecchio, 2000; Robins et al., 2001; Roberts et al., 2006), and even from adolescence to adulthood there is "more stability than change" (Roberts et al., 2001). That means that someone who scores in the top decile of the distribution in one trait is quite likely to score in the top again when surveyed years later. Personality type consistency is

\footnotetext{
${ }^{6}$ The standard test was the Stanford-Binet IQ test that Terman himself had recently developed (Terman, 1916). Some of the participants took the closely related "Terman Group Test", specifically designed for screening these high achieving children (see Chapter I in Terman and Sears, 2002). Its scale was such that scores are comparable. In the subsequent analyses, I always allow for the possibility that there were differences between the two measures of IQ, by including an interaction with test type. The coefficients of the two tests are never statistically different from each other. The well-known Stanford-Binet IQ test has naturally undergone updates throughout its life time, notably to make it less verbally loaded, to measure domain-specific ability (such as verbal vs. quantitative), and to extend the age ranges to children younger than six and adults (overview in Becker, 2003). The latter is not of concern to the sample here, as the students were in the appropriate age range the test was designed for. The worry about a strong verbal content in an IQ test is that it puts children from non-native English households or from different cultural backgrounds at a disadvantage. In the selected sample at hand, this would imply that these usually disadvantaged children would have a higher IQ than their score lets us believe. In all analyses, this paper controls for parental immigrant status, and excludes non-Caucasian participants to address this potential bias. The original Stanford-Binet was only concerned with assessing general ability, which is conceptualized as the aggregate of domain-specific abilities. It is therefore the ultimate summary measure. Given that the current analysis mostly views IQ, within a rather restricted range, as a control variable, controlling for the general version seems appropriate, making the loss of specificity a small one.
} 
quite high (Specht et al., 2014). ${ }^{7}$ The question of the rank order stability of traits remains actively debated in personality psychology, and there is more nuanced evidence: Some events decrease the rank stability, and stability generally follows an inverted U-shape for most traits, with the most stability between age 40-60 (Specht et al., 2011; Lucas and Donnellan, 2011). This implies that in Terman, where traits were measured around age 12 and age 30, these early measures of traits would be relatively noisy proxies for ages both before and after they were measured. It does not imply that they can not be used as proxies, however, since the range of rank stability remains high, between .55 at its lowest to .75 at its highest (Specht et al., 2011). Thus, this paper assumes that measures at one point in time can proxy personality before and after this measurement. While there are some voices in the personality psychology debate who argue that most of personality is situational - that there is very little stable information content - the evidence for important longrun associations of traits with later life outcomes is overwhelming, based on both observational and experimental data (Heckman et al., 2013; Moffitt et al., 2011; Spengler et al., 2015) and controlling for common family factors (Fletcher, 2013).

The Terman survey's control variables include father's and mother's background information (education, occupation group indicators, social status, region of origin, age at birth of subject), family environment (family's finances when growing up, number of siblings, birth order), and early childhood health (birth weight, breastfeeding, sleep quality in 1922). They are summarized in Table 1. The estimation sample consists of 595 men and 422 women of the standard sample. For these individuals, personality items are given and all covariates are measured. Only Caucasian participants without hereditary diseases are included to ensure a homogenous sample. The full selection procedure is described in the Web Appendix, Section A.6.

\section{The Overall Association of Personality Traits and IQ with Lifetime Earnings}

The first order of business must be to establish the overall association of personality traits with lifetime earnings in Terman, conditioning on baseline covariates. This overall association would be comprised of both direct effects of these traits on wages, as well as any intermediate outcomes of traits that also drive earnings. Examples of such intermediate outcomes are working hours, health, retirement age, and education. Education plays a particular role in the literature, therefore it will be discussed explicitly in Section 3.

\subsection{Total Lifetime Earnings}

Begin with the most aggregated form of earnings, the sum of earnings over the life span between age 18 and 75 . Regress this sum, $\bar{Y}$, on personality traits and IQ (in vector $\theta$ ), and all covariates from Table 1 in $X$.

$$
\bar{Y}=\theta \delta+X \beta+\rho
$$

The parameters of interest are in $\delta$, where $\beta$ are the coefficients on covariates, and $\rho$ is the remaining error term. In this linear OLS specification, ${ }^{8}$ a specific type of bias can be corrected: it arises

\footnotetext{
${ }^{7}$ At the same time, there is consensus in the literature that personality itself changes across the life span, in specific mean-level maturation patterns (Soto et al., 2011).

${ }^{8}$ The results here are robust to other estimator types, as shown in Web Appendix Section C.8, but OLS is less data hungry than nonparametric estimators and therefore more suited to the relatively small Terman sample.
} 
Table 1: Descriptive Statistics of the Terman Sample used

\begin{tabular}{|c|c|c|c|c|c|c|}
\hline \multirow{2}{*}{\multicolumn{3}{|c|}{$\begin{array}{l}\text { Earnings in 1,000 USD } \\
\end{array}$}} & \multicolumn{2}{|c|}{ Males } & \multicolumn{2}{|c|}{ Females } \\
\hline & & & Mean & Std.dev & Mean & Std.dev \\
\hline & Age $18-30$ & & 21.4 & (23.74) & 21.1 & $(23.44)$ \\
\hline & Age $31-40$ & & 65.9 & $(51.19)$ & 62.3 & $(42.72)$ \\
\hline & Age 41-55 & & 96.2 & (79.69) & 82.5 & $(66.74)$ \\
\hline & Age $55-75$ & & 50.7 & $(76.14)$ & 36.5 & $(60.01)$ \\
\hline & Lifetime Earnings Total & & 3391 & $(2392)$ & 2811 & (1916) \\
\hline \multicolumn{2}{|c|}{ Education Levels } & Year & \#Obs & $\%$ & \#Obs & $\%$ \\
\hline & High school & 1991 & 56 & $9 \%$ & 45 & $11 \%$ \\
\hline & Some college & 1991 & 95 & $16 \%$ & 76 & $18 \%$ \\
\hline & Bachelor's/ some graduate & 1991 & 174 & $29 \%$ & 181 & $43 \%$ \\
\hline & Master's or equivalent & 1991 & 113 & $19 \%$ & 96 & $23 \%$ \\
\hline & Ph.D. or equivalent & 1991 & 157 & $26 \%$ & 24 & $6 \%$ \\
\hline \multicolumn{2}{|c|}{ Control Variables } & Year & Mean & Std.dev & Mean & Std.dev \\
\hline \multirow{16}{*}{ 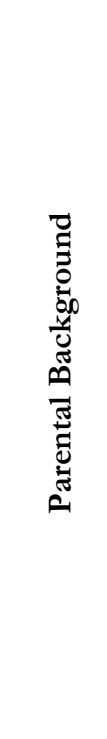 } & Father's highest school grade & 1922 & 12.3 & $(3.61)$ & 12.1 & $(3.62)$ \\
\hline & Mother's highest school grade & 1922 & 11.6 & $(2.83)$ & 11.7 & $(2.95)$ \\
\hline & Father's occupation: professional & 1922 & $25 \%$ & $(0.43)$ & $28 \%$ & $(0.45)$ \\
\hline & Father's occ.: semi-professional, business & 1922 & $26 \%$ & $(0.44)$ & $24 \%$ & $(0.43)$ \\
\hline & Father's occ.: clerical & 1922 & $22 \%$ & $(0.41)$ & $22 \%$ & $(0.42)$ \\
\hline & Father's occ.: low-skilled, farmer & 1922 & $16 \%$ & $(0.37)$ & $15 \%$ & $(0.36)$ \\
\hline & At least one parent is retired/no info/deceased & 1922 & $12 \%$ & $(0.33)$ & $12 \%$ & $(0.33)$ \\
\hline & Mother is housewife / minor occupation & 1922 & $89 \%$ & $(0.32)$ & $90 \%$ & $(0.30)$ \\
\hline & Mother's occupation: skilled, not housewife & 1922 & $11 \%$ & $(0.32)$ & $10 \%$ & $(0.30)$ \\
\hline & Father's age when child was born & 1922 & 33.4 & $(8.00)$ & 34.2 & $(7.67)$ \\
\hline & Mother's age when child was born & 1922 & 28.6 & $(5.39)$ & 29.5 & $(5.36)$ \\
\hline & Either parent is born in Europe & 1922 & $13 \%$ & $(0.34)$ & $12 \%$ & $(0.32)$ \\
\hline & Childhood family finances (very) limited & 1950 & $38 \%$ & $(0.49)$ & $38 \%$ & $(0.49)$ \\
\hline & Childhood family finances adequate/vary & 1950 & $58 \%$ & $(0.49)$ & $57 \%$ & $(0.50)$ \\
\hline & Childhood family finances abundant & 1950 & $4 \%$ & $(0.20)$ & $6 \%$ & $(0.23)$ \\
\hline & Childhood parental social status - high & 1950 & $35 \%$ & $(0.48)$ & $33 \%$ & $(0.47)$ \\
\hline \multirow{2}{*}{$\frac{1}{\infty} \stackrel{\infty}{\infty}$} & Number of siblings & 1940 & 1.8 & $(1.60)$ & 1.8 & $(1.62)$ \\
\hline & Birth order & 1940 & 1.8 & $(1.27)$ & 2.0 & $(1.39)$ \\
\hline \multirow{3}{*}{ 至全 } & No breastfeeding & 1922 & $9 \%$ & $(0.29)$ & $9 \%$ & $(0.29)$ \\
\hline & Birthweight in kilograms & 1922 & 3.8 & $(0.65)$ & 3.6 & $(0.63)$ \\
\hline & Sleep is sound & 1922 & $97 \%$ & $(0.17)$ & $98 \%$ & $(0.14)$ \\
\hline \multirow{3}{*}{ 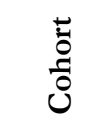 } & Cohort: 1904-1910 & & $56 \%$ & $(0.50)$ & $53 \%$ & $(0.50)$ \\
\hline & Cohort: 1911-1915 & & $44 \%$ & $(0.50)$ & $47 \%$ & $(0.50)$ \\
\hline & WWII combat experience & 1945 & $10 \%$ & $(0.30)$ & $0 \%$ & $(0.07)$ \\
\hline
\end{tabular}

Note: Earnings refer to own earnings for men, and family earnings (sum of own and husband's earnings, if any, for women. 
Table 2: The Total Association of Traits with Lifetime Earnings

\begin{tabular}{|c|c|c|c|c|c|c|c|c|c|}
\hline & \multicolumn{3}{|c|}{ Men } & \multicolumn{6}{|c|}{ Women } \\
\hline & \multirow[b]{2}{*}{ USD } & \multirow[b]{2}{*}{$\%$} & \multirow[b]{2}{*}{ [CI] } & \multicolumn{3}{|c|}{ Own Earnings } & \multicolumn{3}{|c|}{ Family Earnings } \\
\hline & & & & USD & $\%$ & {$[\mathrm{CI}]$} & USD & $\%$ & {$[\mathrm{CI}]$} \\
\hline Openness & -102.2 & -3.0 & $\begin{array}{r}{[-338.0} \\
114.7]\end{array}$ & $93.2^{*}$ & 13.3 & $\begin{array}{l}{[-7.9} \\
\quad 220.2]\end{array}$ & -141.2 & -5.0 & $\begin{array}{r}{[-490.6 ;} \\
117.3]\end{array}$ \\
\hline Conscientiousness & $567.0^{* * *}$ & 16.7 & $\begin{array}{c}{[328.0} \\
832.5]\end{array}$ & $155.3^{* * *}$ & 22.2 & $\begin{array}{c}{[62.4 ;} \\
284.2]\end{array}$ & $212.7^{*}$ & 7.6 & $\begin{array}{l}{[-37.8 ;} \\
505.4]\end{array}$ \\
\hline Extraversion & $490.1^{* * *}$ & 14.5 & $\begin{array}{c}{[260.0} \\
773.8]\end{array}$ & -56.9 & -8.1 & $\begin{array}{r}{[-183.2} \\
40.1]\end{array}$ & $284.6^{* *}$ & 10.1 & $\begin{array}{l}{[13.4 ;} \\
\quad 664.7]\end{array}$ \\
\hline Agreeableness & $-267.6^{* *}$ & -7.9 & $\begin{array}{r}{[-570.5} \\
-6.4]\end{array}$ & -63.2 & -9.0 & $\begin{array}{r}{[-203.3} \\
46.3]\end{array}$ & 72.1 & 2.6 & $\begin{array}{r}{[-234.2 ;} \\
403.0]\end{array}$ \\
\hline Neuroticism & -12.4 & -0.4 & $\begin{array}{r}{[-186.3} \\
185.6]\end{array}$ & $-76.0^{*}$ & -10.9 & $\begin{array}{r}{[-164.1} \\
2.8]\end{array}$ & 13.4 & 0.5 & $\begin{array}{r}{[-193.1 ;} \\
219.9\end{array}$ \\
\hline $\mathrm{IQ}$ & $184.1^{* *}$ & 5.4 & $\begin{array}{l}{[22.5 ;} \\
367.7]\end{array}$ & 2.5 & 0.4 & $\begin{array}{c}{[-66.4 ;} \\
64.3]\end{array}$ & -44.1 & -1.6 & $\begin{array}{r}{[-231.2} \\
172.6\end{array}$ \\
\hline Mean Life Earn. & 3390.5 & & & 700.0 & & & 2811.1 & & \\
\hline
\end{tabular}

Note: Standardized coefficients of traits from regressing total lifetime earnings in thousand USD (2010), ages 18 to 75, on the full set of control variables in Table 1, not educational attainment (cf. Eq. (1)). The "\%"-columns express the effect as a share of mean lifetime earnings, and "CI" are the observed $5^{\text {th }}$ and $95^{\text {th }}$ percentiles of the corresponding bootstrap distribution to allow for asymmetric confidence bands, from 1000 paired replications. Asterisks indicate p-values, the probability of observing an absolutely larger value of the test statistic under a Null hypothesis of no effect on average, with ${ }^{*}(p<.10),{ }^{* *}(p<$ $.05),{ }^{* * *}(p<.01)$. Number of observations: 595 men, 422 women.

because factor scores for personality traits are predicted on the basis of estimates of a factor model, so their values contain prediction uncertainty and have higher sample variance than the true factors. This attenuation bias is often ignored by economists using predicted factor scores, which might explain insignificant effects of these factor scores (see the discussion in Thiel and Thomsen, 2013). I correct for this estimation error with the method suggested by Croon (2002). It consists of characterizing the bias precisely and pre-multiplying the point estimates with the inverse of an estimate of the bias term, which uses the covariance of the true factors from the factor estimation. All regression results in this paper are corrected for this bias, and all standard errors are bootstrapped non-parametrically, following standard practice (Bolck et al., 2004), because regular standard errors do not take account of the prediction variance and the fact that the measurement system is estimated. A bootstrap distribution obtained from 1000 draws is used to report standard bootstrap p-values and bootstrap percentile confidence bands. These are preferred to symmetric confidence bands using standard errors because the bootstrap distribution is not gaussian, and with asymmetric distributions and slightly heavy tails, application of standard hypothesis tests using standard errors is inappropriate.

The results of this regression, in Table 2, demonstrate that, conditional on IQ and family background characteristics, there are statistically and economically significant associations be- 
tween personality traits and lifetime earnings. Men who score one standard deviation higher on Conscientiousness have over half a million USD higher lifetime earnings, a sum of $\$ 567,000$ that corresponds to $16.7 \%$ of average lifetime earnings. The association of Extraversion with men's earnings is almost as large, at $\$ 490,100$. For women's family earnings, the two traits of Conscientiousness and Extraversion also have the largest associations, even if their magnitude is smaller than for men, at $\$ 212,700$ and $\$ 284,600$, respectively. ${ }^{9}$ Generally, the positive effects of the two traits of Extraversion and Conscientiousness are expected: Conscientiousness is directly linked to productivity (Cubel et al., 2016), and it is consistently associated with increased wages (Judge et al., 1999) and better job performance (see Salgado, 1997 and the meta-analyses of Barrick and Mount, 1991 and Mount et al., 1998). Extraversion also has been found to increase job performance, particularly in management and sales occupations (Barrick and Mount, 1991), and it is positively correlated with leadership ability (meta-analysis in Judge et al., 2002).

More agreeable men earn significantly less. Agreeableness increasing by one standard deviation is associated with a reduction of about $8 \%$ of lifetime earnings, or $\$ 267,600$. This might be surprising when thinking about which personality traits are likely to be valued by employers. More agreeable employees are less antagonistic and more likely to act towards others' interests instead of their own, therefore they are more likely to cooperate with the employer (Bowles et al., 2001). They also perform better in teamwork situations (Mount et al., 1998). However, these workers might not be rewarded for their agreeableness because they could be less aggressive in wage bargaining. It is also possible that agreeable individuals select into lower-paying occupations, or that they have lower manipulative power, or 'Machiavellian intelligence' (Turner and Martinez, 1977, pointed out by Nyhus and Pons, 2005). Neuroticism is expected to decrease earnings. More secure and less anxious workers have better job performance (Barrick and Mount, 1991; Salgado, 1997; Mount et al., 1998). Self-esteem, which has been linked to emotional stability (Judge et al., 1998), has been shown to have positive effects on wages (Murnane et al., 2001; Goldsmith et al., 1997). In the Terman sample, however, there is no evidence of this negative association for men, only women's own earnings. Subsequent sections will provide suggestive evidence that the men's null finding hides heterogeneity by education.

IQ has a positive association with earnings for men of this sample - a possibly surprising result given the range of IQ in Terman, which compares very-high-IQ individuals to even-higher-IQ individuals. The positive significant coefficient of $\$ 184,100$, a $5 \%$ increase in lifetime earnings, clearly contradicts statements made in Gladwell (2008) that for the Terman men, IQ does not matter empirically once family background and other observable personal characteristics are taken into account. The popularized view that "past a certain threshold, having even higher IQ does not matter" has already been contradicted before (Lubinski, 2016).

For a causal interpretation of these global associations in Table 2, several assumptions are necessary that will be discussed in turn. Generally, one would have to assume that no unobserved variables remain that are correlated with both personality traits and earnings. Typical candidates for this worry are family background or other skills. This paper relies on a "selection on observables" or matching assumption. This approach exploits the unique strengths of the Terman data: all regressions include control variables for family background, respondent information, IQ, and all personality traits simultaneously.

Education could be highlighted as one possible omitted variable: One would worry that higher

\footnotetext{
${ }^{9}$ There are remarkable differences between the association of traits with women's own and their family earnings. They are better understood in the context of education and marriage - a discussion postponed to Section 4.
} 
education fosters Conscientiousness, and that the association of Conscientiousness with earnings reflects actually only a return to education-because Conscientiousness is measured when many have completed their education. While this is a worry that cannot be addressed directly with the data at hand, there is no evidence that Conscientiousness is fostered in higher education (Kassenboehmer et al., forthcoming; Schurer, 2017), and on the contrary there is something inherent in Conscientiousness that directly improves productivity (Cubel et al., 2016). The only trait that seems to be increased through schooling is Extraversion (Dahmann and Anger, 2014), which is measured at around age 12 in Terman, when all participants are still in compulsory schooling.

Another specific concern to the current setting is reverse causality and timing. Adult traits could be influenced by prior labor market success. If personality traits are measured before the outcome, this concern is alleviated (cf Piatek and Pinger, 2016). In Terman, three skills are measured at around age 12, clearly before labor market entry (IQ, Openness to Experience, and Extraversion). Three traits are measured in 1940, when participants are around 30 years old: Conscientiousness, Agreeableness, and Neuroticism. It is indeed possible that the associations in Table 2 partially reflect effects of early earnings on these three traits. Theoretically, it can be noted that for the reverse causality to be dominant, the following would need to hold: The traits prior to 1940 would have to be relatively unrelated to the 1940 measurement (low rank stability), or the early earnings would have to be relatively unrelated to the early traits, and at the same time there would have to be a strong effect of a random early wage shock on subsequent traits in 1940. Empirically, there is little evidence for such a strong relationship of previous earnings on traits. Cobb-Clark and Schurer (2013) show that Locus of Control, another socio-emotional skill, does not change systematically with labor market or health events. In Judge et al. (1999), the correlations of Big Five traits with adult income and occupational status are practically identical between childhood personality measures and measures taken in adulthood. Furthermore, I test whether conditioning the 1940 traits on early labor market success alters the results, but it does not (see Section C.7 in the Appendix).

\subsection{Life-Cycle Pattern of the Overall Effect by Age}

With these caveats in mind, we can proceed to study when in a working life personality traits matter most. Equation (1) can be estimated for each age separately, as in

$$
Y_{t}=\theta \delta_{t}+X \beta_{t}+\rho_{t} \quad \text { for } t=1, \ldots, T \text {. }
$$

Figure 1 shows the corresponding estimates for men (for women, the patterns are very similar but noisier, see Web Appendix Section C.2). The age-specific effects of Conscientiousness, Extraversion, and IQ only begin to materialize when workers are in their early thirties. Then, the effects continue to increase throughout their forties, up to $\$ 10,000-\$ 20,000$ annually, for an increase by one standard deviation. At younger ages, the effects of traits are small and insignificant. Similar patterns have been found for cognitive ability by Hause (1972), Farber and Gibbons (1996), and Altonji and Pierret (2001). ${ }^{10}$ Socio-emotional skills have also been found to have effects on earnings that increase with age in Kuhn and Weinberger (2005), as leadership skills' effects only begin to emerge "some 7 to 8 years after high school."

\footnotetext{
${ }^{10}$ These authors approximate cognitive ability with performance on achievement tests that are not only driven by cognitive ability. See Almlund et al. (2011) for a discussion of the non-cognitive component of achievement tests.
} 
Figure 1: The Overall Effect of Personality and IQ on Earnings, Men
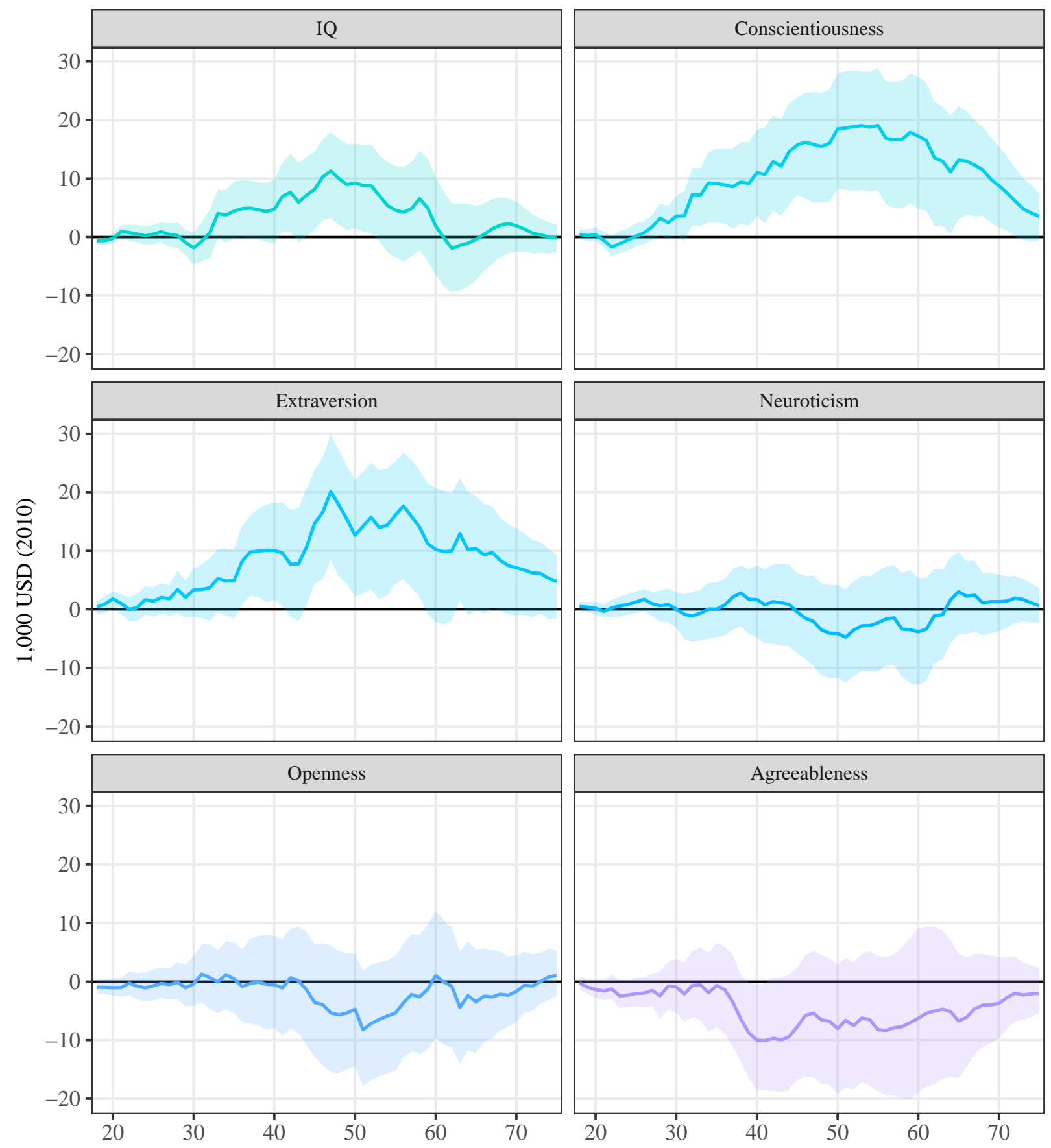

Participant's Age

Note: Standardized coefficients $\delta_{t}$ from Eq. (2) on earnings after tuition, holding background factors constant. The shaded areas are standard bootstrap 95\%-confidence bands from 1000 draws. 
Two mechanisms could explain the pattern of insignificant findings early in the career and strong effects from age 40 to 60 , both related to wage returns to skills. The first is employer learning. Increasing returns to skills could reflect the sequential revelation of a worker's true ability (Altonji and Pierret, 2001; Jovanovic, 1979; Miller, 1984; Farber and Gibbons, 1996). Initially, as employers do not yet observe a person's character traits or socio-emotional skills, they cannot price these skills into wages. The empirical evidence for this hypothesis is rather weak, however. The coefficients on interactions of skills with actual tenure are insignificant in Heineck and Anger (2010), Heineck (2011), and Nyhus and Pons (2005).

The second hypothesis is related to occupational sorting and hierarchies. Socio-emotional skills may matter meaningfully only once the worker has climbed the rungs of the ladder and is in a leadership position himself. While being extraverted and conscientious could be appreciated by his superiors at all levels, these traits have a reasonably larger impact on other team members and, therefore, overall productivity, once he supervises others. This explanation is more directly related to the nature of these socio-emotional skills.

Another explanation of the strong earnings effects later in life could be given by the link between personality and health or work effort. Both hours worked and length of working life enter the sum of annual earnings measures in Terman, as they are not log hourly wages (retired workers remain in the panel with zero earnings). Conscientiousness plays an important role for health and to increase longevity (Friedman et al., 1993; Savelyev, 2012). More conscientious individuals are less likely to experience the chronic illnesses that are main predictors of mortality (Mokdad et al., 2004; Goodwin and Friedman, 2006), at least partly because they display better health-related behaviors, such as fewer activities that endanger health (Lodi-Smith et al., 2010). Consequently, they are less likely to retire early for health reasons (extensive margin), and may have more energy to continue working regular hours (intensive margin).

Note that none of the suggested mechanisms, or the empirical evidence they are based on, are specific to high-IQ individuals. Also, the concave life-cycle pattern can be found for several traits and IQ, and has been detected in other (more representative) samples. This could suggest that the mechanisms would also work in samples without Terman's selectivity in terms of IQ, and that they could generate the same shape of lifetime effects. To the extent that this pattern can be attributed to general mechanisms that are not specific to high-IQ individuals, the results from the Terman sample could be used to extrapolate out, for example, treatment effects after early skill-building interventions that do not have a long follow-up. Having access to data with both measures of personality traits and IQ with long follow-up is essential to pick up on this shape of effects by age. The Terman results are also more informative of lifetime-effects than simple wage regressions at one point in time because here the intensive and extensive margins of labor supply are accounted for in the long run.

\section{Conditional Effects of Personality Traits and IQ, Men}

So far, I have presented the overall association of traits with earnings, comprising numerous potential channels. As mentioned, one channel stands out in importance: education. There is pervasive evidence that more conscientious individuals have higher educational attainment (Noftle and Robins, 2007; O'Connor and Paunonen, 2007). Piatek and Pinger (2016) argue that for Locus of Control, another facet of personality, the largest wage effects are indeed due to its effect on educational attainment. 
Education has a causal effect on earnings. Since personality traits influence educational attainment, they generate an indirect return through education. Thus, one would want to condition on education to establish which effect of personality traits remains as a "direct effect," irrespective of education. To decompose these direct and indirect effects, consider an earnings regression for lifetime earnings $\bar{Y}$ that, in addition to traits, IQ, and observable characteristics $(\theta$ and $X)$, conditions on educational attainment $j$, indicated by the binary variable $D_{j}$. Schooling attainment is a function of traits and characteristics in $D_{j}(\theta, X)$, and the total number of education levels is $J$ :

$$
\bar{Y}=\theta \delta+\sum_{j=1}^{J} \kappa_{j} D_{j}(\theta, X)+X \beta+\rho
$$

This formulation is a frequent specification. Most economists, in their analyses of the effects of personality traits on earnings, condition on education (see Nyhus and Pons, 2005; Mueller and Plug, 2006; Heineck and Anger, 2010; Heineck, 2011; Duckworth and Weir, 2010; Fletcher, 2013). I will do the same in order to be able to compare results in this Terman cohort with the existing literature. The typical interpretation would be that the "direct," or conditional, effects of traits $\theta$ are given by vector $\delta$. The "indirect" effect would be a combination of the influence of $\theta$ on schooling $D_{j}$, and the treatment effect of schooling, $\kappa_{j}$. The indirect effect will be studied below, in Section 3.3. Despite the advantage of Eq. (3) as a comparison tool, it has to be pointed out that is not as econometrically innocuous as it looks. When personality influences education, the composition of the sample within an education level is not random. Conditional on education, the distribution of traits and unobservables may be different. This implies that a type of selection bias could be present in Eq. (3). This is related to a variant of the omitted variable problem: If someone with low Conscientiousness, for example, obtains high education despite his low Conscientiousness, does he have a strong unobserved skill that also has a positive effect on earnings? In this case, the coefficients of Eq. (3) would underestimate the true effect of $\theta$, because individuals with high Conscientiousness would be compared to individuals with low Conscientiousness but who have strong other skills and therefore above-average earnings. This would depress the coefficient on Conscientiousness. ${ }^{11}$ Therefore, these regressions which are frequently performed can only provide descriptive evidence. The conditional coefficients can suggest relationships and point to potential pathways through education.

\subsection{Lifetime Effects, Conditional on Education}

The leftmost column of Table 3 reports the standardized $\delta$ of Eq. (3), to examine the "direct" effects of personality traits on lifetime earnings for Terman men. They look very similar to Table 2, with large effects of Conscientiousness, Extraversion, and Agreeableness, and a positive effect of IQ. The coefficients on Conscientiousness and IQ are reduced relative to the unconditional regression (f. ex. $\$ 427,900$ instead of $\$ 567,000$ for Conscientiousness). This is to be expected with a positive association of these traits with education, and a positive return to education. The other coefficients remain almost unchanged - also not surprising given the low association of these traits with education.

\footnotetext{
${ }^{11}$ The econometric challenge of accounting for both education and traits can only be properly addressed with a structural analysis (such as Heckman et al., 2006b), which would be too data-demanding for the Terman sample. It will therefore be left for other samples.
} 
Table 3: Direct Effects of Traits on Men's Lifetime Earnings, Conditional and Interacted with Education

\begin{tabular}{|c|c|c|c|c|c|c|c|c|c|}
\hline & \multicolumn{3}{|c|}{ Direct Effect, Eq. (3) } & \multicolumn{4}{|c|}{ Interacted Effect, Eq. (4) } & \multicolumn{2}{|c|}{ Diff. MA - BA } \\
\hline & USD & $\%$ & CI & & USD & $\%$ & CI & USD & $\mathrm{p}$ \\
\hline \multirow[t]{2}{*}{ Openness } & -162.0 & -4.8 & $\begin{array}{r}{[-415.3} \\
66.6]\end{array}$ & $\leq \mathrm{BA}$ & -101.6 & -3.5 & $\begin{array}{r}{[-363.2 ;} \\
146.9]\end{array}$ & -85.7 & $(0.38)$ \\
\hline & & & & $\geq \mathrm{MA}$ & -187.3 & -4.7 & $\begin{array}{r}{[-576.2 ;} \\
200.0]\end{array}$ & & \\
\hline \multirow[t]{2}{*}{ Conscientious. } & $427.9^{* * *}$ & 12.6 & $\begin{array}{l}{[193.3 ;} \\
682.2]\end{array}$ & $\leq \mathrm{BA}$ & $247.0^{* *}$ & 8.4 & $\begin{array}{l}{[1.0 ;} \\
\quad 501.0]\end{array}$ & 310.5 & $(0.11)$ \\
\hline & & & & $\geq \mathrm{MA}$ & $557.5^{* * *}$ & 14.1 & $\begin{array}{l}{[238.2 ;} \\
898.0]\end{array}$ & & \\
\hline \multirow[t]{2}{*}{ Extraversion } & $485.4^{* * *}$ & 14.3 & $\begin{array}{l}{[265.5 ;} \\
\quad 773.0]\end{array}$ & $\leq \mathrm{BA}$ & $252.6^{* *}$ & 8.6 & $\begin{array}{l}{[1.1 ;} \\
\quad 521.8]\end{array}$ & $414.8^{* *}$ & $(0.05)$ \\
\hline & & & & $\geq \mathrm{MA}$ & $667.4^{* * *}$ & 16.9 & $\begin{array}{l}{[335.4 ;} \\
\quad 1089.6]\end{array}$ & & \\
\hline \multirow[t]{2}{*}{ Agreeableness } & $-300.1^{* *}$ & -8.8 & $\begin{array}{r}{[-600.5 ;} \\
-39.5]\end{array}$ & $\leq \mathrm{BA}$ & -157.7 & -5.4 & $\begin{array}{r}{[-445.5 ;} \\
93.8]\end{array}$ & -250.5 & $(0.17)$ \\
\hline & & & & $\geq \mathrm{MA}$ & $-408.2^{* *}$ & -10.4 & $\begin{array}{c}{[-766.3 ;} \\
-46.9]\end{array}$ & & \\
\hline \multirow[t]{2}{*}{ Neuroticism } & -27.6 & -0.8 & $\begin{array}{r}{[-204.2 ;} \\
165.7]\end{array}$ & $\leq \mathrm{BA}$ & $-160.0^{*}$ & -5.5 & $\begin{array}{r}{[-354.5} \\
21.7]\end{array}$ & $288.2^{*}$ & $(0.06)$ \\
\hline & & & & $\geq \mathrm{MA}$ & 128.2 & 3.3 & $\begin{array}{r}{[-130.6} \\
429.4]\end{array}$ & & \\
\hline \multirow[t]{2}{*}{ IQ } & $151.6^{*}$ & 4.5 & $\begin{array}{c}{[-17.6} \\
332.0]\end{array}$ & $\leq \mathrm{BA}$ & 158.1 & 5.4 & $\begin{array}{l}{[-91.8 ;} \\
\quad 423.3]\end{array}$ & -4.8 & $(0.50)$ \\
\hline & & & & $\geq \mathrm{MA}$ & 153.3 & 3.9 & $\begin{array}{l}{[-73.9 ;} \\
\quad 409.7]\end{array}$ & & \\
\hline
\end{tabular}

Note: The dependent variable is total lifetime earnings in thousand USD, ages 18 to 75. The "Direct Effect" is the standardized coefficient $\delta$ from Eq. (3), which conditions earnings on education. The "Interacted Effects" are standardized education-specific $\delta_{j}$ from Eq. (4). "CI" are the observed $5^{\text {th }}$ and $95^{\text {th }}$ percentiles of the corresponding bootstrap distribution to allow for asymmetric confidence bands, from 1000 paired replications. Columns "\%" express the effects in USD as percentages of mean lifetime earnings (education-specific for Eq. (4)). "Diff. MA-BA" lists the premium of "MA or more" ( $\geq M A)$ over "BA or less" ( $\leq B A)$ from Eq. (4), and tests equality in column " $p$ " with p-values reflecting the probability of observing an absolutely larger value of the test statistic under a Null hypothesis of no effect on average. These p-values are also the basis for the asterisks in the main effect columns, with ${ }^{*}(p<.10),{ }^{* *}(p<.05),{ }^{* * *}(p<.01)$. Number of observations: 595. 
Since the Terman sample is admittedly particular - in terms of cognitive ability and cohort - it is conceivable that these effects of traits are unique to this sample. Yet they are generally in line with other research on samples that are not selective in terms of IQ, and which are more recent: As here, Conscientiousness is consistently found to have a positive effect; this is shown by O'Connell and Sheikh (2011) on the basis of the NCDS, a representative panel of a 1958 birth cohort in the UK, Heineck (2011) with the UK's BHPS, Prevoo and ter Weel (2015) with the 1970 British Cohort Study, Heineck and Anger (2010) with the representative German panel SOEP (years 1991-2006), Duckworth and Weir (2010) with the U.S. Health and Retirement Study, and many more. The effect of Agreeableness is also in agreement with these samples, and in addition with Mueller and Plug (2006), who use the Wisconsin Longitudinal Study (which can be considered representative for white high school students). One of the strongest effects in the Terman sample is given by Extraversion, which also does not seem to be unique to the cohort studied here, or to high-IQ men: Most of the existing research confirms this positive association (Judge et al., 1999; Heineck and Anger, 2010; O'Connell and Sheikh, 2011; Fletcher, 2013). The null finding on Openness to Experience is unsurprising, as previous studies show mixed results: It increases earnings in Mueller and Plug (2006) and O'Connell and Sheikh (2011), but has a negative effect in Heineck and Anger (2010). Because of its positive correlation with IQ, the effect of Openness may be biased upward in analyses that do not control for IQ (such as Heineck, 2011). The only real point of disagreement between the results here and the literature is about Neuroticism: It has a consistently negative association with wages in Nyhus and Pons (2005); Heineck (2011); O'Connell and Sheikh (2011); Judge et al. (1999); Mueller and Plug (2006).

\subsection{Lifetime Effects, Interaction with Education}

Let us continue the analysis of conditional earnings effects of personality traits, but test for heterogeneous effects by educational attainment. This addresses the question of for whom traits matter the most. Consider the following modification of Eq. (3), where the magnitude of the "direct" effects $\delta_{j}$ may vary by educational attainment $j$.

$$
\bar{Y}=\theta \sum_{j=1}^{J} \delta_{j} D_{j}(\theta, X)+\sum_{j=1}^{J} \kappa_{j} D_{j}(\theta, X)+X \beta+\rho .
$$

Note that to correct the prediction error bias, Croon's method needs to be expanded because of the interaction of traits $\theta$ with education $D_{j}$. I derive the correction that accounts for this interaction in Section B.3 of the Web Appendix.

The rightmost columns of Table 3 list the $\delta_{j}$ of Eq. (4); the direct effects of traits on total lifetime earnings interacted with two levels of education $j$, "Bachelor's or less" $(\leq \mathrm{BA})$ and "Master's or more" ( $\geq \mathrm{MA}$ ). A finer distinction would be desirable, but is not feasible with the relatively small sample. The two largest positive effects, of Conscientiousness and Extraversion, reveal a pattern of heterogeneity: The reward to being more conscientious or extraverted is much greater for more highly educated men. At the graduate level $(\geq \mathrm{MA})$, an increase in those traits would lead to an earnings gain of $\$ 557,500$ or $\$ 667,400$, more than twice as much as the increase for men with a bachelor's or less $(\$ 247,000$ and $\$ 252,600) .{ }^{12}$ The difference between the reward of these traits by

\footnotetext{
${ }^{12}$ In percentage terms, the difference looks smaller because they are expressed as percent of average earnings by education level.
} 
educational level is statistically significant for Extraversion, as tested in the column "Differences." The interaction between traits and education has previously only been tested by Nyhus and Pons (2005), who also report a positive differential, for Extraversion only.

In magnitude, the gains from an increase in one of these traits by one standard deviation is comparable to half the value of a college degree. As Section 3.3.2 will show, the net present value of a bachelor's over a high school degree is $\$ 1,072,400$ for Terman men. Thus, the combined value of an increase in both Conscientiousness and Extraversion by one standard deviation would be even larger than the value of that degree.

With respect to Agreeableness, it seems that the negative effect is also larger for more educated men $(\$ 408,200$ vs $\$ 157,700)$. The difference, however, is not statistically significant. The interaction also sheds light on the surprising non-negative effect of Neuroticism in the overall association in the Terman sample. Highly educated men of this sample are indeed not punished for high Neuroticism scores (insignificant positive coefficient), but the standard negative effect is confirmed in less educated men (significant $-\$ 160,000$ ). The difference between the two is statistically significant.

What could explain the finding that traits have stronger effects on earnings for more educated men? First, it could reflect true human capital differences. Existing skills enter the production function of human capital. Self-productivity of skills arises if individuals who enter school with a higher stock of human capital produce more human capital for each unit of schooling (Cunha and Heckman, 2007), similar to the complementarity between schooling and IQ found in Hause (1972). Little will be learned at school without dedication and preparation, participation in class, interactions with teachers and peers. Thus, more conscientious and extraverted men acquire more human capital in school, and have a higher stock of human capital at the end than the less conscientious and extraverted with the same educational degree. This difference in human capital might be reflected in the additional positive effect of these traits on wages.

The second reason why some traits would be rewarded more highly for more educated men is related to occupational differences by schooling. Choice sets from which individuals choose their occupations will differ by education. It is thus possible that more highly educated men are better able to choose occupations that reward their traits than less educated men. For example, executive positions are much more prevalent in the higher education group. Conscientiousness, Extraversion, and Emotional Stability are significantly associated with "executive strengths" (Holland et al., 1993), and they are positively correlated with leader emergence and leader effectiveness (Judge et al., 2002). Thus, if education opens access to these occupations that would reward the conscientious and extraverted more, there is a higher reward to traits in high education groups. Evidence from other studies indicates that effects of socio-emotional skills on earnings persist even when occupation dummies are included, such as in Heineck (2011). In Kuhn and Weinberger (2005), leadership skills have positive wage effects even within very narrowly-defined occupational groups.

\subsection{Indirect Effects of Traits through Education}

I continue the conditional setup to briefly sketch the indirect effect of traits that works through their influence on educational attainment. First, I establish the effects of personality on education in $D_{j}$ (Section 3.3.1). Then, in Section 3.3.2, I estimate $\kappa_{j}$, the return to education in the Terman sample, to finally combine the two to the indirect effect that can be compared to the "direct" effect. 
Table 4: The Impact of Psychological Traits on Educational Attainment, Men

\begin{tabular}{lccccc}
\hline & HS & Some Coll. & BA & MA & Dr \\
\hline IQ & $-0.035^{* * *}$ & -0.008 & 0.020 & 0.013 & 0.010 \\
& $(0.012)$ & $(0.020)$ & $(0.024)$ & $(0.020)$ & $(0.021)$ \\
Openness & 0.004 & $-0.047^{* *}$ & 0.014 & -0.011 & 0.041 \\
& $(0.009)$ & $(0.020)$ & $(0.029)$ & $(0.025)$ & $(0.026)$ \\
Conscientiousness & $-0.017^{* *}$ & $-0.055^{* * *}$ & $-0.052^{*}$ & 0.032 & $0.092^{* * *}$ \\
& $(0.008)$ & $(0.017)$ & $(0.027)$ & $(0.027)$ & $(0.026)$ \\
Extraversion & $-0.020^{*}$ & 0.020 & -0.014 & 0.004 & 0.010 \\
& $(0.011)$ & $(0.022)$ & $(0.032)$ & $(0.026)$ & $(0.029)$ \\
Agreeableness & -0.007 & 0.021 & -0.018 & -0.021 & 0.025 \\
& $(0.011)$ & $(0.023)$ & $(0.032)$ & $(0.030)$ & $(0.030)$ \\
Neuroticism & 0.008 & $-0.058^{* *}$ & 0.010 & 0.052 & -0.013 \\
& $(0.011)$ & $(0.025)$ & $(0.037)$ & $(0.036)$ & $(0.035)$ \\
\hline
\end{tabular}

Note: Marginal effects of increasing personality traits by one standard deviation, from a generalized ordered logit model, evaluated at means of all covariates (asymptotic standard errors in parentheses). Estimated using Williams (2006) with standard controls, of which a number are constrained to equal coefficients without rejecting $H_{0}$ of proportional odds. P-values based on a two-sided asymptotic test, with ${ }^{*}(p<.10),{ }^{* *}(p<.05),{ }^{* * *}(p<.01)$.

\subsubsection{Educational Attainment as a Function of Traits}

Personality traits in Terman influence education mostly as expected. Table 4 displays marginal effects of a generalized ordered logit model of education choice for men. ${ }^{13}$

Conscientiousness, which is generally the strongest predictor of academic achievement (Noftle and Robins, 2007; Poropat, 2009, 2014), also has a positive effect here. A one standard deviation increase raises the probability of a doctorate degree by 9 percentage points, and lowers the probability of a bachelor's or less by 5.2 percentage points. Conscientiousness likely enhances education through lowering the psychic costs of education, or lowering the discount rate. The "hard working" elements of Conscientiousness, effortful control and attention regulation (MacCann et al., 2009; Duckworth et al., 2012), imply that a conscientious person perceives the effort required in schooling as less costly. The "future planning" element can be associated with lower discount rates for deferred gains.

Openness also raises schooling of the Terman males slightly - it decreases the probability of them remaining at below a bachelor's degree, even conditioning on IQ. Individuals high in Openness would enjoy learning and intellectual endeavors more, reducing their psychic cost or increasing their consumption value of schooling.

IQ significantly decreases the chances of remaining in high school, the lowest education category (-3.5 percentage points).

Neuroticism decreases the probability of the "Some College" option by 5.8 percentage points.

\footnotetext{
${ }^{13}$ Since the correction method applied in other results of this paper is limited to least squares regressions, inference here ignores the prediction error introduced by using predicted personality factors.
} 
This finding diverges from previous studies, where Emotional Stability is positively associated with educational attainment.

\subsubsection{The Return to Education at Average Traits}

Having established that psychological traits determine educational choice, how does education translate into lifetime earnings? I can provide observed ex-post returns on individual earnings histories that do not require the standard assumptions for using cross-sectional data in Mincer equations $^{14}$ (Becker and Chiswick, 1966; Mincer, 1974). Other assumptions are necessary, however, to identify the return to education, $\kappa_{j, t}$. In Terman, it requires a "selection on observables" or matching assumption, on the basis of a standard Roy model (see Web Appendix), because there is currently no appropriate exogenous variation in education available. It would have to be a) at the margin to college and graduate school, b) for a sample of high-IQ men and women, and c) around the year 1930. ${ }^{15}$ While a source of exogenous variation in schooling would be desirable at least for a comparison, the rich background information available in the Terman data allow to control for the selection into schooling at a much greater level of detail than usually possible: ability both in the cognitive and in the socio-emotional domain is observed, as is parental background, and the sample is relatively homogenous in terms of location and environment. If the existing research that uses exogenous variation can be any guide to the high-IQ sample of Terman men and women, one would expect the matching estimates to be conservative in the sense that they would typically be lower than those from instrumental variables (Card, 1999).

Based on the matching assumption, the average treatment effect of education level $j$ vs. $k$ at each age $t$ corresponds to $\kappa_{j, t}-\kappa_{k, t}$ from Eq. (4) by age. At the mean, factor scores are zero, therefore in these average effects, the interaction with psychological traits drops out. The right half of Table 5 provides, for each pairwise comparison of educational attainment, the sum of all agewise earnings differences. These are the net present values, undiscounted so as to be comparable to the effects of traits. The left half lists the internal rate of return (IRR) that summarizes the age-by-age effects, to compare to rates of return known in the literature. The returns are generally large. In comparison to having a high school diploma, obtaining a bachelor's degree increases the Terman males' earnings by a total of $\$ 1,072,400$ over a lifetime. The corresponding IRR is $12.2 \%$. This estimate implies that even for the highly talented Terman men with IQs above 140, going to school substantially contributed to increasing their lifetime earnings, and the rate of return to this investment exceeds that of the return on equity. ${ }^{16}$ The average returns to graduate and

\footnotetext{
${ }^{14}$ Results from a Mincer equation estimated with Terman data is in Appendix Section C.10.

${ }^{15}$ The usual candidates for instrumental variables are not useful in the Terman context. For example, changes in compulsory schooling laws (Angrist and Krueger, 1991, or Lleras-Muney, 2005) would not alter the attainment of a group that does not have a single high school dropout, and of which a quarter obtained doctoral degrees. For the college margin, changes in public student aid (Dynarski, 2003) or changes in tuition levels (Kane and Rouse, 1993) are bound to be weak instruments, as this group of high-IQ individuals could easily obtain tuition wavers or scholarships from private sources. Distance to nearest college (Card, 1993) may have been appropriate, but the Terman data lack information on original residence within California. Local labor market conditions have sometimes been used as exclusion restrictions, but precise information would be difficult to obtain for this period, and it is not clear whether it is a valid instrument given what is known about the effects of graduating in a recession, and how the effects vary by student quality (Oreopoulos et al., 2012).

${ }^{16}$ The $12.2 \%$ return to a bachelor's is comparable in magnitude to an estimate from the census. Earnings differences between college and high school in the 1950 census yield a rate of return estimate of $10.7 \%$, using the nonparametric procedure described in Heckman et al. (2006a). Using the same procedure on the Terman data (and ignoring the rich covariates) produces a rate of return to a bachelor's degree of $11.4 \%$. The reason that these returns are comparable
} 
Table 5: Pairwise Average Treatment Effects on Earnings, Males

\begin{tabular}{|c|c|c|c|c|c|c|c|c|}
\hline & \multicolumn{4}{|c|}{ Internal Rate of Return } & \multicolumn{4}{|c|}{ Net Present Value, undiscounted } \\
\hline & Some Coll. & Bachelor & Master & Doctorate & Some Coll. & Bachelor & Master & Doctorate \\
\hline High School & $\begin{array}{c}11.1 \\
{[-14.0,28.3]}\end{array}$ & $\begin{array}{c}12.2 \\
{[5.3,18.3]}\end{array}$ & $\begin{array}{c}8.3 \\
{[3.9,13.1]}\end{array}$ & $\begin{array}{c}9.2 \\
{[6.1,12.6]}\end{array}$ & $\begin{array}{c}344.4 \\
{[-315,1009]}\end{array}$ & $\begin{array}{c}1072.4 \\
{[420,1715]}\end{array}$ & $\begin{array}{c}1002.3 \\
{[283,1702]}\end{array}$ & $\begin{array}{c}1689.5 \\
{[1022,2400]}\end{array}$ \\
\hline Some College & & $\begin{array}{c}13.0 \\
{[1.5,21.3]}\end{array}$ & $\begin{array}{c}7.3 \\
{[2.7,13.1]}\end{array}$ & $\begin{array}{c}8.8 \\
{[5.3,12.3]}\end{array}$ & & $\begin{array}{c}732.8 \\
{[184,1271]}\end{array}$ & $\begin{array}{c}662.6 \\
{[78,1224]}\end{array}$ & $\begin{array}{c}1349.8 \\
{[740,1970]}\end{array}$ \\
\hline Bachelor & & & $\begin{array}{c}-2.0 \\
{[-13.8,50.4]}\end{array}$ & $\begin{array}{c}6.0 \\
{[1.5,11.5]}\end{array}$ & & & $\begin{array}{c}-65.4 \\
{[-582,482]}\end{array}$ & $\begin{array}{c}621.8 \\
{[58,1194]}\end{array}$ \\
\hline Master & & & & $\begin{array}{c}13.5 \\
{[-0.6,25.0]}\end{array}$ & & & & $\begin{array}{c}690.9 \\
{[152,1273]}\end{array}$ \\
\hline
\end{tabular}

Note: The effects of education on earnings are evaluated for males with average personality traits, as in Eq. (4), and brackets show 95\% confidence bands are from 1000 bootstrap draws. Earnings are annual earnings after tuition in 1,000 U.S. Dollars (of the year 2010), with the top 3\% of values truncated. Covariates are IQ, factor scores for personality traits, parental background, family environment, childhood health, and cohort controls. The Internal Rate of Return is the discount rate that would make an individual indifferent between obtaining more education or remaining at a baseline level ( $j$ vs. $k$ ), the $\rho$ such that $\sum_{t=18}^{75} \frac{\left(\kappa_{j, t}-\kappa_{k, t}\right)}{(1+\rho)^{t-17}}=0$. 
Figure 2: Decomposition of Marginal Effects of Traits, Men

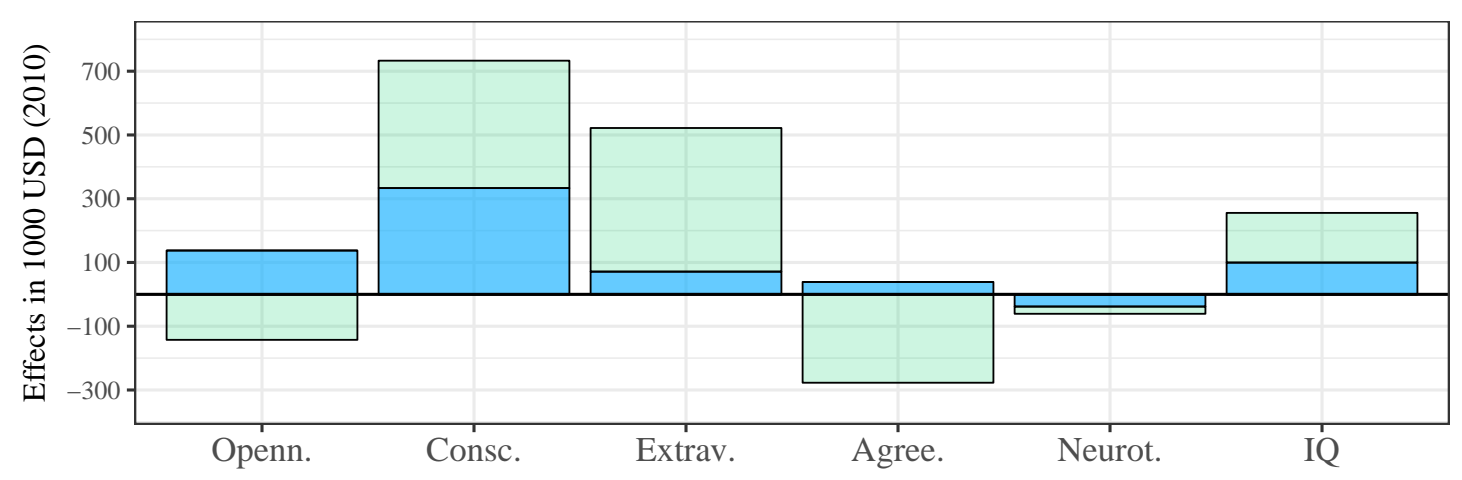

Indirect Effect through Education Direct Effect of Trait

Note: Stacked marginal effects showing how much an increase of one standard deviation in each personality trait influences total lifetime earnings. Determined according to the following derivative of Eq. (4), evaluated at means of all covariates and traits (where indirect(alt.direct) evaluates to zero at the mean of traits):

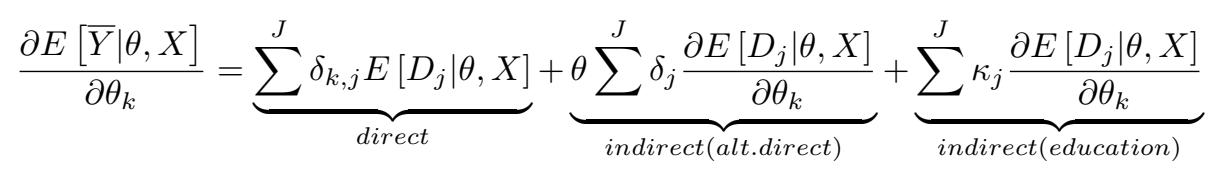

postgraduate degrees are also substantial. The net present values document that a doctorate over high school, for example, yields 1.5 times as much as a college degree, or near 1.7 million USD. (Note that IRRs can be misleading when they hide the large positive net lifetime values.) The earnings histories in the Terman sample can thus establish that the return to education is high even among individuals with the highest cognitive abilities. The "valedictorian" does not necessarily have higher returns than his peers with average ability, but solid returns at comparable rates. Even in a high ability group, education adds skills that are valued in the marketplace.

\subsubsection{Decomposition of Total Effect of Traits on Lifetime Earnings}

Multiplying the marginal effect of traits on education with the return to education yields the total "indirect effect" from Eq. (4). It can be contrasted to the "direct" effect (Section 3.1). Figure 2 shows this decomposition of the effects of traits on lifetime earnings, obtained from taking the total derivative of Eq. (4) with respect to $\theta_{k}$. For most traits, the direct effect on earnings outweighs the indirect effect through education. This implies that researchers should focus on interpretations that relate traits directly to earnings rather than to education. Only Conscientiousness, and to some extent Openness, have significant indirect returns through education.

is that Terman men's earnings are higher at both education levels. Since Terman men with a high school diploma earn substantially more than the average man from the census, the opportunity cost of schooling is much higher. 


\section{Conditional Effects of Personality Traits and IQ, Women}

After studying when and for whom personality traits matter most in terms of lifetime earnings for men, this section briefly completes the analysis for women. The direct analogy is challenged by the historical nature of the Terman sample, which is more visible for women than for men of this cohort. The women belonged to a generation in which their role was still mainly that of a homemaker, mother, and wife. A woman's freedom to choose a career or define her lifestyle was not what it is today. About half of the Terman women were housewives, despite their extraordinary abilities. While most of the housewives did not earn a market wage, they could still increase their potential family earnings through socio-emotional skills and education by matching with a husband with higher educational achievement and earnings.

\subsection{Lifetime Effects, Conditional and Interacted with Education}

In terms of own earnings, women of this cohort generally did not benefit from their socioemotional skills - see the left column of Table 6. The point estimates are much smaller than the corresponding estimates for men, and are not significantly different from zero. The only exception to this finding is Conscientiousness. This positive association (overall $\$ 129,200$ for a 1 -standarddeviation increase) is purely driven by highly educated women (effect of $\$ 343,600$ ). In this sense, only women with a post-graduate education benefited from their human capital as the men of this sample did. They still did not reach the men's level, however, since the magnitude of their reward is about $60 \%$ of that of men with equal education (cf Table 3). Note that in generations following the Terman women, Conscientiousness is associated with higher earnings, as Mueller and Plug (2006) demonstrate already for women born around 1940.

The effects of personality traits on women's family earnings reveal important heterogeneities by education: Analyses that ignore the interaction between personality and education may overor under-state the effects of personality traits in average impacts. For example, while the highly educated women in Terman could expect a return to Conscientiousness from own earnings, they did not benefit in terms of family earnings (insignificant coefficient). Less educated women, instead, saw higher family earnings from this trait (positive significant coefficient of $\$ 299,300$. The key lies in the effect of Conscientiousness on husbands' earnings: it decreased husbands' earnings of highly educated women, but increased them for less educated women. This could mean that less educated conscientious women married more frequently, or higher earning husbands, or both. While this question cannot be answered definitively with the Terman sample, a supplementary analysis (Web Appendix Section C.6) suggests that, at the bachelor level or less, more conscientious women married higher earning husbands. For women with graduate education, Conscientiousness had a negative effect on the probability of being married. It also made them more likely to be in a high-wage job for an extended time. The negative effect on husband's earnings completely offset the positive effect of own earnings in $\delta_{j}$.

In the effects of Openness, Extraversion, and IQ, strong differential effects by education are also present. Women with a college degree who scored higher on Openness had lower spousal and family earnings $(-\$ 400,900)$, but their highly educated counterparts had significant gains from this trait $(\$ 511,500)$. This gain through the marriage market stands in contrast to men, where Openness did not have a significant direct effect on lifetime earnings. More extraverted women with at most a college education benefited greatly in terms of family earnings $(\$ 524,500)$. This seems to be the result of two positive effects: they were more likely to marry than introverts, and if they did, they married husbands with higher earnings. Women with a master's degree or more, however, had 
Table 6: The Direct Effects of Traits on Women's Lifetime Earnings

\begin{tabular}{|c|c|c|c|c|c|c|c|}
\hline \multirow{2}{*}{ Openness } & \multicolumn{4}{|c|}{ Own Earnings } & \multicolumn{3}{|c|}{ Family Earnings } \\
\hline & Direct & Int & t. & Diff. & Direct & Interact. & Diff. \\
\hline Openness & $\begin{array}{c}25.2 \\
{[-77,142]}\end{array}$ & $\begin{array}{l}\leq \mathrm{BA} \\
\geq \mathrm{MA}\end{array}$ & $\begin{array}{c}23.7 \\
{[-103,148]} \\
47.9 \\
{[-293,548]}\end{array}$ & $\begin{array}{c}24.3 \\
(0.42)\end{array}$ & $\begin{array}{c}-187.0 \\
{[-562,56]}\end{array}$ & $\begin{array}{c}-400.9^{* *} \\
{[-958,-106]} \\
511.5^{*} \\
{[-126,1558]}\end{array}$ & $\begin{array}{c}912.4^{* *} \\
(0.01)\end{array}$ \\
\hline onscientiousn. & $\begin{array}{l}129.9^{* *} \\
{[39,250]}\end{array}$ & $\begin{array}{l}\leq \mathrm{BA} \\
\geq \mathrm{MA}\end{array}$ & $\begin{array}{c}60.5 \\
{[-37,172]} \\
343.6^{* *} \\
{[75,810]}\end{array}$ & $\begin{array}{c}283.1^{* *} \\
(0.05)\end{array}$ & $\begin{array}{c}207.7^{*} \\
{[-46,507]}\end{array}$ & $\begin{array}{c}299.3^{* *} \\
{[14,701]} \\
-28.9 \\
{[-843,659]}\end{array}$ & $\begin{array}{c}-328.2 \\
(0.18)\end{array}$ \\
\hline Extr: & $\begin{array}{c}-31.9 \\
{[-152,65]}\end{array}$ & $\begin{array}{l}\leq \mathrm{BA} \\
\geq \mathrm{MA}\end{array}$ & $\begin{array}{c}-0.4 \\
{[-135,132]} \\
-122.0 \\
{[-480,107]}\end{array}$ & $\begin{array}{l}-121.6 \\
(0.18)\end{array}$ & $\begin{array}{l}316.5^{* *} \\
{[50,722]}\end{array}$ & $\begin{array}{c}524.5^{* * *} \\
{[188,1144]} \\
-314.2 \\
{[-1066,139]}\end{array}$ & $\begin{array}{c}-838.7^{* *} \\
(0.01)\end{array}$ \\
\hline Agreeableness & $\begin{array}{c}-37.6 \\
{[-167,71]}\end{array}$ & $\begin{array}{l}\leq \mathrm{BA} \\
\geq \mathrm{MA}\end{array}$ & $\begin{array}{c}-51.1 \\
{[-184,67]} \\
28.4 \\
{[-378,462]}\end{array}$ & $\begin{array}{c}79.5 \\
(0.32)\end{array}$ & $\begin{array}{c}107.9 \\
{[-197,463]}\end{array}$ & $\begin{array}{c}207.4 \\
{[-135,678]} \\
-200.2 \\
{[-1282,567]}\end{array}$ & $\begin{array}{r}-407.6 \\
(0.17)\end{array}$ \\
\hline Neuroticism & $\begin{array}{c}-59.9^{*} \\
{[-142,12]}\end{array}$ & $\begin{array}{l}\leq \mathrm{BA} \\
\geq \mathrm{MA}\end{array}$ & $\begin{array}{c}-28.2 \\
{[-127,60]} \\
-141.3 \\
{[-412,96]}\end{array}$ & $\begin{array}{l}-113.1 \\
(0.22)\end{array}$ & $\begin{array}{c}30.7 \\
{[-184,246]}\end{array}$ & $\begin{array}{c}-0.6 \\
{[-316,279]} \\
-52.1 \\
{[-608,340]}\end{array}$ & $\begin{array}{l}-51.5 \\
(0.42)\end{array}$ \\
\hline IQ & $\begin{array}{c}20.3 \\
{[-43,82]}\end{array}$ & $\begin{array}{l}\leq \mathrm{BA} \\
\geq \mathrm{MA}\end{array}$ & $\begin{array}{c}6.3 \\
{[-64,78]} \\
9.3 \\
{[-242,219]}\end{array}$ & $\begin{array}{l}147.7 \\
(0.15)\end{array}$ & $\begin{array}{c}-32.6 \\
{[-219,184]}\end{array}$ & $\begin{array}{c}79.6 \\
{[-129,385]} \\
-477.3^{* *} \\
{[-1062,-102]}\end{array}$ & $\begin{array}{l}131.7 \\
(0.26)\end{array}$ \\
\hline
\end{tabular}

Mean Life Earn. 700.0

2811.1

Note: Standardized coefficient estimates from Eq. (3) in column "Direct," and Eq. (4) in "Interact.", with differences MA-BA in "Diff.". Square brackets show observed $5^{\text {th }}$ and $95^{\text {th }}$ percentiles of the corresponding bootstrap distribution, and p-values in round parentheses are the probability of observing an absolutely larger value of the test statistic under a Null hypothesis of no effect on average, with ${ }^{*}(p<.10),{ }^{* *}(p<.05),{ }^{* * *}(p<.01)$. See further notes to Table 3. Number of observations: 422. 
Table 7: The Impact of Personality Traits and IQ on Educational Attainment, Women

\begin{tabular}{lccccc}
\hline & HS & Some Coll. & BA & MA & Dr \\
\hline IQ & -0.007 & -0.031 & 0.048 & 0.004 & -0.014 \\
& $(0.007)$ & $(0.024)$ & $(0.035)$ & $(0.095)$ & $(0.091)$ \\
Openness & 0.000 & -0.009 & -0.048 & 0.032 & 0.025 \\
& $(0.011)$ & $(0.033)$ & $(0.041)$ & $(0.172)$ & $(0.169)$ \\
Conscientiousness & -0.003 & $-0.057^{*}$ & -0.026 & 0.079 & 0.007 \\
& $(0.011)$ & $(0.033)$ & $(0.043)$ & $(0.058)$ & $(0.047)$ \\
Extraversion & $0.024^{* *}$ & 0.021 & -0.045 & 0.020 & -0.020 \\
& $(0.010)$ & $(0.030)$ & $(0.036)$ & $(0.138)$ & $(0.135)$ \\
Agreeableness & $0.040^{* *}$ & -0.014 & -0.008 & -0.006 & -0.012 \\
& $(0.016)$ & $(0.040)$ & $(0.048)$ & $(0.089)$ & $(0.081)$ \\
Neuroticism & $0.050^{* * *}$ & -0.026 & -0.010 & 0.003 & -0.017 \\
& $(0.018)$ & $(0.043)$ & $(0.050)$ & $(0.120)$ & $(0.113)$ \\
\hline
\end{tabular}

Note: Marginal effects from a generalized ordered logit model, evaluated at means of all covariates (standard errors in parentheses). P-values based on a two-sided asymptotic test, with ${ }^{*}(p<.10),{ }^{* *}(p<.05),{ }^{* * *}(p<.01)$. See notes to Table 4 .

statistically insignificant effects of extraversion. IQ had a strong negative impact for women with a master's or doctorate degree $(-\$ 477,300)$, because their probability of being married was lower. In contrast to Conscientiousness, however, IQ was unrelated to labor supply in this range - thus husband's earnings were reduced without an increased probability of work.

\subsection{Indirect Effects of Traits through Education, Women}

For women of the Terman study, the influence of personality traits on educational attainment was weaker than for men. Nevertheless, the associations between education and Extraversion and Neuroticism are similar to findings from representative samples. These traits increased the probability of women to remain in the lowest schooling category (although they are not significantly affecting higher schooling levels). In terms of returns to education, I focus on family earnings. For women with a bachelor's degree, the returns to education were positive. They did not have any payoff from their studies in terms of own earnings, but they benefited from the marriage market: they were just as likely to marry as women without a college education, but they married more educated and higher-earning husbands. ${ }^{17}$ This led to a net value of $\$ 152,000$. For women with graduate education, the odds of being married declined strongly. This translated to negative returns to education on the marriage market for women with a master's degree, as they did not, on average, compensate their lower propensity to marry with higher husband's earnings. The few women who obtained a doctorate degree saw large returns to education in terms of own earnings, but they had to accept penalties in the marriage market, as they were less likely to be married. Conditional on being married, their husbands had above-average earnings. Overall, there was

\footnotetext{
${ }^{17}$ Again, these supplemental analyses are presented in Section C.6 of the Appendix.
} 
Table 8: Female Internal Rates of Return and Net Present Values, Family Earnings

\begin{tabular}{|c|c|c|c|c|c|c|}
\hline & \multicolumn{3}{|c|}{ Internal Rate of Return } & \multicolumn{3}{|c|}{ Net Present Value, undiscounted } \\
\hline & Bachelor & Master & Doctorate & Bachelor & Master & Doctorate \\
\hline High School & $\begin{array}{c}18.7 \\
{[6.6,37.0]}\end{array}$ & {$\left[\begin{array}{l}{[-.]} \\
{[}\end{array}\right.$} & $\begin{array}{c}13.3 \\
{[0.9,43.3]}\end{array}$ & $\begin{array}{c}152 \\
{[-418,719]}\end{array}$ & $\begin{array}{c}-21 \\
{[-595,600]}\end{array}$ & $\begin{array}{c}573 \\
{[-510,2151]}\end{array}$ \\
\hline Bachelor & & [.- . .] & $\begin{array}{c}10.3 \\
{[-37.8,49.6]}\end{array}$ & & $\begin{array}{c}-172 \\
{[-746,470]}\end{array}$ & $\begin{array}{c}422 \\
{[-630,2097]}\end{array}$ \\
\hline Master & & & $\begin{array}{c}21.0 \\
{[-18.6,71.9]}\end{array}$ & & & $\begin{array}{c}595 \\
{[-421,2197]}\end{array}$ \\
\hline
\end{tabular}

Note: Internal rates of return and net present values are based on the age-by-age treatment effects of education from Eq. (4). The results on own and husband's earnings separately are in Section C.1 of the Web Appendix. See Table 5 for more notes.

a positive return to family earnings as the return to own work outweighed the lower husband's earnings (net values of $\$ 422,000-\$ 595,000$, noisily estimated).

The decomposition of the direct and indirect effects on family earnings in Fig. 3 demonstrates that indirect effects through education did not matter much for women of the Terman samplebecause education only changed earnings for the very highly educated, and traits did not influence the decision to obtain a doctorate degree sufficiently to generate strong indirect effects.

\section{Summary and Conclusion}

This paper estimates the effects of personality traits and IQ on lifetime earnings of the men and women of the Terman study. The traits of Conscientiousness and Extraversion have strong, positive associations with men's lifetime earnings, and Agreeableness a negative association. While the Terman sample is selective in terms of IQ, these results mirror prior findings that are based on representative samples. They show that even men with exceptional cognitive skills benefit from socio-emotional skills.

Personality traits and IQ do not affect the levels of earnings equally at all ages: the question of when they matter can be answered with "especially in the prime working years." A humpshape life-cycle pattern is distinctly present in several traits, where the earnings effect of traits is initially insignificant, rises to be the largest around ages 40-60, and drops off afterwards. If the life-cycle pattern that is observed for this high-IQ group is driven by mechanisms that are also at work in the general population, one could expect the same hump-shape to be present generally. Some of the potential mechanisms that are discussed - health and behaviors, employer learning or work hierarchies - are not unique to high-IQ individuals, as empirical evidence suggests. Naturally, there could still be a difference in magnitudes because the Terman participants combine their socio-emotional skills with high cognitive ability. Nevertheless, a concave life-cycle pattern would suggest implications for research that relies on cross-sectional data with young workersfor these, the current association of traits with earnings could underestimate the association with 
Figure 3: Total Marginal Effects of Traits, Women's Family Earnings

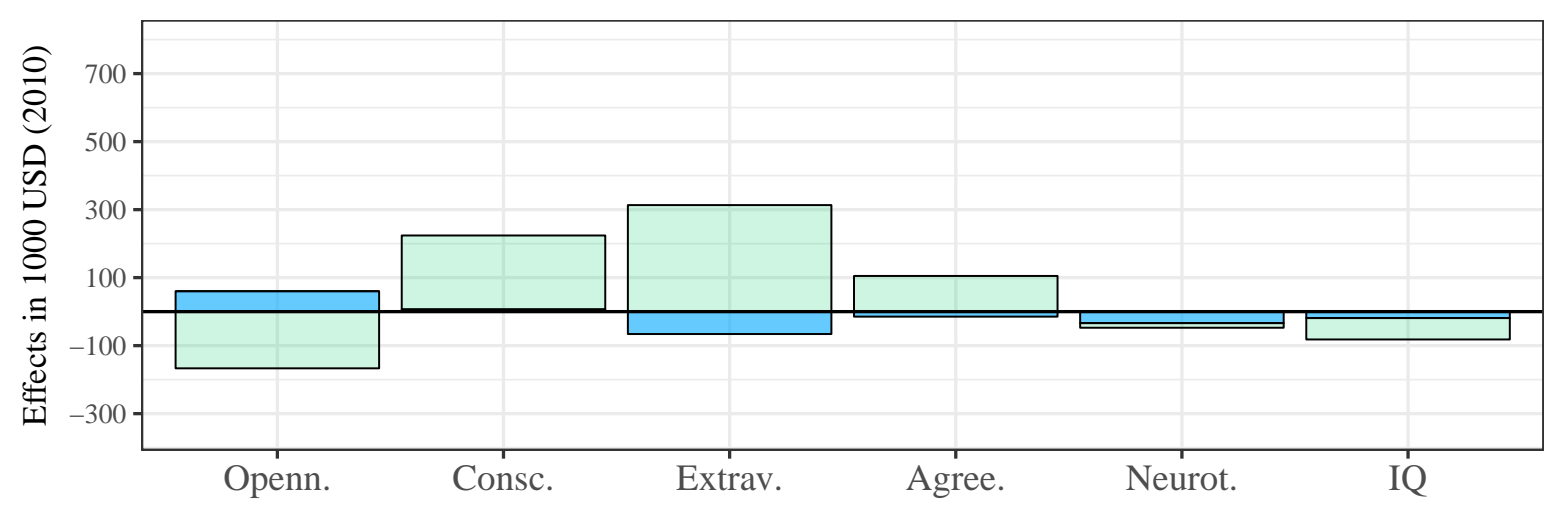

Indirect Effect through Education Direct Effect of Trait

Note: See notes to Fig. 2.

lifetime earnings. The concave pattern would also have implications for evaluations of early-life interventions that only have a short follow-up. Again, if the conversion of socio-emotional skills into earnings works similarly for those participating in skill-building interventions as for the Terman sample, one could expect that initially low associations of changed traits with earnings would eventually turn into greater associations later in life. Since in the Terman study, the largest earnings effects of personality traits occur later in life, cost-benefit analyses of interventions should account appropriately for expected future gains.

In an exploratory analysis, I condition on traits and education simultaneously in the earnings regression. Significant interaction terms demonstrate that men with graduate degrees experience greater effects of their traits than their less educated counterparts. The educational heterogeneity answers the question of who benefits most from socio-emotional skills.

Some personality traits, especially Conscientiousness, also affect educational sorting. Combined with a positive return to education, they produce an indirect effect on earnings. The estimates of the returns to education rely on matching on an unusually extensive list of covariates, including IQ and personality. The fully observed lifetime earnings show that the returns to education for the Terman men are sizeable. The indirect effect through education and the remaining "direct" earnings effect can be contrasted. This decomposition illustrates the relative importance of the indirect effect for Conscientiousness only. For the other traits, the remaining mechanisms dominate.

For women of this cohort, the effects of personality on own earnings were weaker than for men, reflecting the historical nature of this sample. Their traits nevertheless influenced their family earnings, through the probability of being married and husbands' earnings. Higher education generally reduced income through the husband, but women with a doctorate degree had very high earnings on their own. 
Almlund, M., Duckworth, A. L., Heckman, J. J., Kautz, T., 2011. Personality Psychology and Economics. In: Hanushek, E. A., Machin, S., Woessmann, L. (Eds.), Handbook of the Economics of Education, Vol. 4. Vol. 4. Elsevier B.V., Ch. 1, pp. 1-181.

URL http://dx.doi.org/10.1016/B978-0-444-53444-6.00001-8

Altonji, J. G., Pierret, C. R., 2001. Employer Learning and Statistical Discrimination. The Quarterly Journal of Economics 116 (1), 313-350.

American Psychological Association, 2007. APA Dictionary of Psychology. American Psychological Association, Washington, DC.

Angrist, J. D., Krueger, A. B., 1991. Does Compulsory School Attendance Affect Schooling and Earnings? The Quarterly Journal of Economics 106 (4), 979-1014.

Barrick, M. R., Mount, M. K., 1991. The Big Five Personality Dimensions and Job Performance: A Meta-Analysis. Personnel Psychology 44 (1), 1-26. URL http://doi.wiley.com/10.1111/j.1744-6570.1991.tb00688.x

Bartlett, M., 1937. The Statistical Conception of Mental Factors. British Journal of Psychology 1 (28), 97-104.

Becker, G. S., Chiswick, B. R., 1966. Education and the Distribution of Earnings. The American Economic Review $56(1 / 2), 358-369$.

Becker, G. S., Landes, E. M., Michael, R. T., 1977. An Economic Analysis of Marital Instability. Journal of Political Economy 85 (6), 1141-1187.

Becker, K. A., 2003. History of the Stanford-Binet Intelligence Scales: Content and Psychometrics. In: Stanford-Binet Intelligence Scales, Assessment Service Bulletin Number 1. Rivserside Publishing, Itasca, IL.

Bolck, A., Croon, M., Hagenaars, J., 2004. Estimating Latent Structure Models with Categorical Variables: 1-Step Versus 3-Step Estimators. Political Analysis 12 (1), 3-27.

URL http://pan.oupjournals.org/cgi/doi/10.1093/pan/mph001

Borghans, L., Duckworth, A. L., Heckman, J. J., ter Weel, B., 2008. The Economics and Psychology of Personality Traits. Journal of Human Resources 43 (4), 972-1059.

Bowles, S., Gintis, H., Osborne, M., 2001. Incentive-Enhancing Preferences: Personality, Behavior, and Earnings. The American Economic Review 91 (2), 155-158.

Caliendo, M., Cobb-Clark, D. A., Uhlendorff, A., 2015. Locus of Control and Job Search Strategies. The Review of Economics and Statistics 97 (1), 88-103.

Card, D., 1993. Using Geographic Variation in College Proximity to Estimate the Return to Schooling. NBER Working Paper Series (4483).

URL http://www.nber.org/papers/w4483.pdf?new\{_\}window=1

Card, D., 1999. The Causal Effect of Education on Earnings. In: Ashenfelter, O., Card, D. (Eds.), Handbook of Labor Economics, Vol. 3. Vol. 3. Elsevier Science B.V., Ch. 30, pp. 1801-1863.

Cobb-Clark, D. A., Schurer, S., 2013. Two Economists' Musings on the Stability of Locus of Control. The Economic Journal 123 (570), F358-F400.

URL http://doi.wiley.com/10.1111/ecoj.12069

Costa, P. T. J., McCrae, R. R., 1994. Set like Plaster? Evidence for the Stability of Adult Personality. In: Heatherton, T. F., Weinberger, J. L. (Eds.), Can personality change? American Psychological Association, Washington, D.C., U.S.A., pp. 21-40.

Croon, M., 2002. Using Predicted Latent Scores in General Latent Structure Models. In: Marcoulides, G. A., Moustaki, I. (Eds.), Latent Variable and Latent Structure Models. Lawrence Erlbaum Associates, Inc., Ch. 10, pp. 195-223.

Cubel, M., Nuevo-Chiquero, A., Sanchez-Pages, S., Vidal-Fernandez, M., 2016. Do Personality Traits Affect Productivity? Evidence from the Lab. The Economic Journal 126 (May), 654-681.

URL http: //papers.ssrn. com/abstract $=2471066$

Cunha, F., Heckman, J. J., 2007. The Technology of Skill Formation. The American Economic Review: Papers and Proceedings $97(2), 31-47$.

Dahmann, S., Anger, S., 2014. The Impact of Education on Personality: Evidence from a German High School Reform. IZA Discussion Paper (8139).

Dauber, S. L., Benbow, C. P., 1990. Aspects of Personality and Peer Relations of Extremely Talented Adolescents. Gifted Child Quarterly 34 (1), 10-14.

URL http://gcq. sagepub.com/cgi/doi/10.1177/001698629003400103

Duckworth, A. L., Quinn, P. D., Tsukayama, E., 2012. What No Child Left Behind leaves behind: The roles of IQ and self-control in predicting standardized achievement test scores and report card grades. Journal of Educational Psychology 104 (2), 439-451. 
Duckworth, A. L., Weir, D., 2010. Personality, Lifetime Earnings, and Retirement Wealth. Research Brief, University of Michigan Retirement Research Center (235).

URL http: //www.ssrn.com/abstract=1710166

Dynarski, S. M., 2003. Does Aid Matter? Measuring the Effect of Student Aid on College Attendance and Completion. The American Economic Review 93 (1), 279-288.

Farber, H. S., Gibbons, R., 1996. Learning and Wage Dynamics. Quarterly Journal of Economics 111 (4), $1007-1047$.

Fletcher, J. M., 2013. The effects of personality traits on adult labor market outcomes: Evidence from siblings. Journal of Economic Behavior \& Organization 89, 122-135.

URL http://dx.doi.org/10.1016/j.jebo.2013.02.004

Friedman, H. S., 2008. The multiple linkages of personality and disease. Brain, Behavior, and Immunity 22 (5), 668-675.

Friedman, H. S., Tucker, J. S., Tomlinson-Keasey, C., Schwartz, J. E., Wingard, D. L., Criqui, M. H., 1993. Does Childhood Personality Predict Longevity? Journal of Personality and Social Psychology 65 (1), 176-85.

URL http://www.ncbi.nlm.nih.gov/pubmed/8355139

Gladwell, M., 2008. Outliers: The Story of Success. ittle, Brown and Company, New York, NY.

Goldberg, L. R., 1993. The Structure of Phenotypic Personality Traits. The American Psychologist 48 (1), $26-34$.

Goldsmith, A. H., Veum, J. R., Darity, W. J., 1997. The Impact of Psychological and Human Capital on Wages. Economic Inquiry XXXV (October), 815-829.

Goodwin, R. D., Friedman, H. S., 2006. Health Status and the Five-factor Personality Traits in a Nationally Representative Sample. Journal of Health Psychology 11 (5), 643-54.

URL http://www.ncbi.nlm.nih.gov/pubmed/16908463

Grossman, J. B., Tierney, J. P., 1998. Does Mentoring Work? An Impact Study of the Big Brothers Big Sisters Program. Evaluation Review 22 (3), 403-426.

URL http://erx.sagepub.com/cgi/doi/10.1177/0193841X9802200304

Hamermesh, D. S., 1984. Life-Cycle Effects on Consumption and Retirement. Journal of Labor Economics 2 (3), 353-370.

Hause, J. C., 1972. Earnings Profile: Ability and Schooling. Journal of Political Economy 80 (3, Part 2), S108-S138.

Heckman, J. J., Lochner, L. J., Todd, P. E., 2006a. Earnings Functions, Rates of Return and Treatment Effects: The Mincer Equation and Beyond. In: Hanushek, E. A., Welsh, F. (Eds.), Handbook of the Economics of Education, Vol. 1. Elsevier, Ch. 7, pp. 307-458.

Heckman, J. J., Moon, S. H., Pinto, R., Savelyev, P. A., Yavitz, A., 2010. The rate of return to the HighScope Perry Preschool Program. Journal of Public Economics 94 (1-2), 114-128. URL http://linkinghub.elsevier.com/retrieve/pii/S0047272709001418

Heckman, J. J., Pinto, R., Savelyev, P. A., 2013. Understanding the Mechanisms Through Which an Influential Early Childhood Program Boosted Adult Outcomes. The American Economic Review 103 (6), 2052-2086.

Heckman, J. J., Stixrud, J., Urzua, S., 2006b. The Effects of Cognitive and Noncognitive Abilities on Labor Market Outcomes and Social Behavior. Journal of Labor Economics 24 (3), 411-482.

URL http://www.jstor.org/stable/10.1086/504455

Heineck, G., 2011. Does it Pay to be Nice? Personality and Earnings in the United Kingdom. Industrial and Labor Relations Review 64 (5), 1020-1038.

Heineck, G., Anger, S., 2010. The returns to cognitive abilities and personality traits in Germany. Labour Economics 17 (3), 535-546.

URL http://linkinghub.elsevier.com/retrieve/pii/S0927537109000670

Holland, J. L., Johnston, J. A., Asama, N. F., Polys, S. M., 1993. Validating and Using the Career Beliefs Inventory. Journal of Career Development 19 (4), 233-244.

URL http://jcd.sagepub.com/cgi/doi/10.1177/089484539301900401

Jöreskog, K., Sörbom, D., 1979. Advances in Factor Analysis and Structural Equation Models. Abt Books, Cambridge, Massachusetts.

Jovanovic, B., 1979. Job Matching and the Theory of Turnover. The Journal of Political Economy 87 (5), 972-990.

Judge, T. A., Bono, J. E., Ilies, R., Gerhardt, M. W., 2002. Personality and Leadership: A Qualitative and Quantitative Review. Journal of Applied Psychology 87 (4), 765-780.

URL http://doi.apa.org/getdoi.cfm?doi=10.1037/0021-9010.87.4.765

Judge, T. A., Higgins, C. A., Thoresen, C. J., Barrick, M. R., 1999. The Big Five Personality Traits, General Mental Ability, and Career Success Across the Life Span. Personnel Psychology 52 (3), 621-652.

Judge, T. A., Locke, E. A., Durham, C. C., Kluger, A. N., 1998. Dispositional Effects on Job and Life Satisfaction: The Role of Core Evaluations. Journal of Applied Psychology 83 (1), 17-34. 
Kane, T. J., Rouse, C. E., 1993. Labor-Market Returns to Two- and Four-Year Colleges: Is a credit a credit and do degrees matter? NBER Working Paper Series (4268).

URL http://www.nber.org/papers/w4268

Kassenboehmer, S. C., Leung, F., Schurer, S., forthcoming. University education and noncognitive skill development. Oxford Economic Papers.

Kuhn, P., Weinberger, C., 2005. Leadership Skills and Wages. Journal of Labor Economics 23 (3), 395-436.

Leibowitz, A., 1974. Home Investments in Children. Journal of Political Economy 82 (2, Part 2: Marriage, Family Human Capital and Fertility (Mar.-Apr.)), S111-S131.

Leon, G. R., Gillum, B., Gillum, R., Gouze, M., 1979. Personality Stability and Change Over a 30-Year PeriodMiddle Age to Old Age. Journal of Consulting and Clinical Psychology 47 (3), 517-24.

URL http://www.ncbi.nlm.nih.gov/pubmed/528720

Lleras-Muney, A., 2005. The Relationship Between Education and Adult Mortality in the United States. Review of Economic Studies 72 (1), 189-221.

URL http://restud.oxfordjournals.org/lookup/doi/10.1111/0034-6527.00329

Lodi-Smith, J., Jackson, J., Bogg, T., Walton, K., Wood, D., Harms, P., Roberts, B. W., 2010. Mechanisms of health: Education and health-related behaviours partially mediate the relationship between conscientiousness and self-reported physical health. Psychological Health 25 (3), 305-319.

Lubinski, D., 2016. From Terman to Today: A Century of Findings on Intellectual Precocity. URL http://rer.sagepub.com/cgi/doi/10.3102/0034654316675476

Lucas, R. E., Donnellan, M. B., 2011. Personality development across the life span: Longitudinal analyses with a national sample from Germany. Journal of Personality and Social Psychology 101 (4), 847-861.

MacCann, C., Duckworth, A. L., Roberts, R. D., 2009. Empirical identification of the major facets of Conscientiousness. Learning and Individual Differences 19 (4), 451-458.

Martin, L. R., Friedman, H. S., 2000. Comparing Personality Scales Across Time: An Illustrative Study of Validity and Consistency in Life-Span Archival Data. Journal of Personality 68 (1), 85-110.

Martin, L. R., Friedman, H. S., Clark, K. M., Tucker, J. S., 2005. Longevity following the experience of parental divorce. Social Science and Medicine 61 (10), 2177-2189.

McCrae, R. R., John, O. P., 1992. An Introduction to the Five-Factor Model and Its Applications. Journal of Personality 60 (2), 175-215.

Michael, R. T., 1976. Factors Affecting Divorce: A Study of the Terman Sample. NBER Working Paper Series (147).

Miller, R. A., 1984. Job Matching and Occupational Choice. Journal of Political Economy 92 (6), 1086. URL http://www . journals . uchicago.edu/doi/abs/10.1086/261276

Mincer, J., 1974. Schooling, Experience and Earnings. Columbia University Press for National Bureau of Economic Research, New York

Moffitt, T. E., Arseneault, L., Belsky, D., Dickson, N., Hancox, R. J., Harrington, H., Houts, R., Poulton, R., Roberts, B. W., Ross, S., Sears, M. R., Thomson, W. M., Caspi, A., 2011. A gradient of childhood self-control predicts health, wealth, and public safety. Proceedings of the National Academy of Sciences 108 (7), 2693-8.

Mokdad, A. H., Marks, J. S., Stroup, D. F., Gerberding, J. L., 2004. Actual Causes of Death in the United States, 2000. JAMA : The Journal of the American Medical Association 291 (10), 1238-45.

URL http://www.ncbi.nlm.nih.gov/pubmed/15657315

Mount, M. K., Barrick, M. R., Stewart, L., 1998. Five-Factor Model of Personality and Performance in Jobs Involving Interpersonal Interactions. Human Performance 11 (2-3), 37-41.

Mueller, G., Plug, E., 2006. Estimating the Effect of Personality on Male and Female Earnings. Industrial and Labor Relations Review 60 (1), 3-22.

Mulaik, S. A., 2010. Foundations of Factor Analysis, 2nd Edition. Chapman \& Hall/ CRC, Boca Raton, FL.

Murnane, R. J., Willett, J. B., Braatz, M. J., Duhaldeborde, Y., 2001. Do different dimensions of male high school students' skills predict labor market success a decade later? Evidence from the NLSY. Economics of Education Review 20 (4), 311-320.

URL http://linkinghub.elsevier.com/retrieve/pii/S027277570000056X

Noftle, E. E., Robins, R. W., 2007. Personality Predictors of Academic Outcomes: Big Five Correlates of GPA and SAT Scores. Journal of Personality and Social Psychology 93 (1), 116-30.

URL http://www.ncbi.nlm.nih.gov/pubmed/17605593

Nyhus, E. K., Pons, E., 2005. The effects of personality on earnings. Journal of Economic Psychology 26 (3), $363-384$. URL http://linkinghub.elsevier.com/retrieve/pii/S0167487004000546

O'Connell, M., Sheikh, H., 2011. 'Big Five' personality dimensions and social attainment: Evidence from beyond the campus. Personality and Individual Differences 50 (6), 828-833. 
URL http://linkinghub.elsevier.com/retrieve/pii/S0191886911000079

O'Connor, M. C., Paunonen, S. V., 2007. Big Five personality predictors of post-secondary academic performance. Personality and Individual Differences 43 (5), 971-990.

URL http://linkinghub.elsevier.com/retrieve/pii/S0191886907001249

Oreopoulos, P., von Wachter, T., Heisz, A., 2012. The Short- and Long-Term Career Effects of Graduating in a Recession. American Economic Journal: Applied Economics 4 (1), 1-29.

Piatek, R., Pinger, P. R., 2016. Maintaining (Locus of) Control? Data Combination for the Identification and Inference of Factor Structure Models. Journal of Applied Econometrics 31, 734-755.

Poropat, A. E., 2009. A meta-analysis of the five-factor model of personality and academic performance. Psychological Bulletin 135 (2), 322-338.

Poropat, A. E., 2014. Other-rated personality and academic performance: Evidence and implications. Learning and Individual Differences 34, 24-32. URL http://dx.doi.org/10.1016/j.lindif.2014.05.013

Prevoo, T., ter Weel, B., 2015. The Importance of Early Conscientiousness for Socio-Economic Outcomes. Evidence from the British Cohort Study. Oxford Economic Papers (2006), 1-46. URL http://oep.oxfordjournals.org/cgi/doi/10.1093/oep/gpv022

Roberts, B. W., Caspi, A., Moffitt, T. E., 2001. The Kids Are Alright: Growth and Stability in Personality Development From Adolescence to Adulthood. Journal of Personality and Social Psychology 81 (4), 670-683. URL http://doi.apa.org/getdoi.cfm?doi=10.1037/0022-3514.81.4.670

Roberts, B. W., DelVecchio, W. F., 2000. The Rank-Order Consistency of Personality Traits From Childhood to Old Age: A Quantitative Review of Longitudinal Studies. Psychological Bulletin 126 (1), 3-25.

Roberts, B. W., Walton, K. E., Viechtbauer, W., 2006. Patterns of Mean-Level Change in Personality Traits across the Life Course: A Meta-Analysis of Longitudinal Studies. Psychological Bulletin 132 (1-25).

Robins, R. W., Fraley, R. C., Roberts, B. W., Trzesniewski, K. H., 2001. A Longitudinal Study of Personality Change in Young Adulthood. Journal of Personality 69 (4), 617-40.

Salgado, J. F., 1997. The Five Factor Model of Personality and Job Performance in the European Community. The Journal of Applied Psychology 82 (1), 30-43.

URL http://www.ncbi.nlm.nih.gov/pubmed/9119797

Savelyev, P. A., 2012. Conscientiousness, Education, and Longevity of High-Ability Individuals. Unpublished manuscript, Vanderbilt University.

Savelyev, P. A., 2014. Socioemotional Skills, Education, and Longevity of High-Ability Individuals. URL https://my ·vanderbilt.edu/petersavelyev/files/2014/12/TermanLongevityPaper-appx.pdf

Savelyev, P. A., Tan, K. K. T., 2015. Socioemotional Skills, Education, and Health-Related Outcomes of High-Ability Individuals.

Schurer, S., 2017. Does education strengthen the life skills of adolescents? IZA World of Labor (June), 1-11. URL https://wol.iza.org/articles/does-education-strengthen-the-life-skills-of-adolescents

Sears, R. R., 1984. The Terman gifted children study. In: Mednick, S., Harway, M., Finello, K. (Eds.), Handbook of Longitudinal Research. Vol. 1. Praeger, New York, pp. 398-414.

Soto, C. J., John, O. P., Gosling, S. D., Potter, J., 2011. Age Differences in Personality Traits from 10 to 65 : Big Five Domains and Facets in a Large Cross-Sectional Sample. Journal of Personality and Social Psychology 100 (2), 330-348.

URL http://www.ncbi.nlm.nih.gov/pubmed/21171787

Specht, J., Egloff, B., Schmukle, S. C., 2011. Stability and change of personality across the life course: The impact of age and major life events on mean-level and rank-order stability of the Big Five. Journal of Personality and Social Psychology 101 (4), 862-882.

URL http://doi.apa.org/getdoi.cfm?doi=10.1037/a0024950

Specht, J., Luhmann, M., Geiser, C., 2014. On the consistency of personality types across adulthood: Latent profile analyses in two large-scale panel studies. Journal of Personality and Social Psychology 107 (3), 540-556. URL http://www.ncbi.nlm.nih.gov/pubmed/25133730

Spengler, M., Brunner, M., Damian, R. I., Lüdtke, O., Martin, R., Roberts, B. W., 2015. Student Characteristics and Behaviors at Age 12 Predict Occupational Success 40 years Later Over and Above Childhood IQ and Parental Socioeconomic Status. Developmental Psychology 51 (9), 1329-1340.

Terman, L. M., e. a., 1992. Terman Life-Cycle Study of Children with High Ability, 1922-1986. Interuniversity Consortium for Political and Social Research [distributor], ICPSR08092-v3. Ann Arbor, MI.

URL http://www .icpsr . umich. edu/icpsrweb/ICPSR/studies/8092

Terman, L., 1916. The measurement of intelligence: An explanation of and a complete guide for the use of the 
Stanford revision and extension of the Binet-Simon Intelligence Scale. Houghton Mifflin, Boston.

Terman, L. M., Sears, R. R., 2002. The Terman Life-Cycle Study of Children with High Ability, 1922-1986. Vol. 1, 1922-1928. Inter-University Consortium for Political and Social Research, Ann Arbor, MI.

Thiel, H., Thomsen, S. L., 2013. Noncognitive skills in economics: Models, measurement, and empirical evidence. Research in Economics 67 (2), 189-214.

URL http://linkinghub.elsevier.com/retrieve/pii/S1090944313000136http://dx.doi.org/10.1016/j. rie.2013.03.002

Tomes, N., 1981. A Model of Fertility and Children's Schooling. Economic Inquiry 19 (2), 209.

Tucker, J. S., Friedman, H. S., Wingard, D. L., Schwartz, J. E., 1996. Marital History at Midlife as a Predictor of Longevity: Alternative Explanations to the Protective Effect of Marriage. Health Psychology 15 (2), 94-101.

Turner, C. F., Martinez, D. C., 1977. Socioeconomic Achievement and the Machiavellian Personality. Sociometry 40 (4), 325-336.

University of Chicago Crime Lab, 2012. BAM - Sports Edition. University of Chicago Crime Labe Research and Policy Brief (July).

Uysal, S. D., Pohlmeier, W., 2011. Unemployment duration and personality. Journal of Economic Psychology 32 (6), 980-992.

URL http://linkinghub.elsevier.com/retrieve/pii/S0167487011000481

Williams, R., 2006. Generalized ordered logit/partial proportional odds models for ordinal dependent variables. The Stata Journal 6 (1), 58-82. 